\title{
PENELITIAN PENGENDALIAN PENGUASAAN TANAH OLEH WARGA NEGARA ASING
}

\section{Trie Sakti SH CN}

\author{
BAB I \\ PENDAHULUAN
}

\subsection{Latar Belakang}

Untuk meningkatkan perekonomian Indonesia, maka Pemerintah mendorong peningkatan investasi terutama dengan cara menarik sebanyak-banyaknya investasi asing untuk menanamkan modalnya di Indonesia. Investasi sangat penting untuk memperkuat perekonomian negara mengingat saat ini perekonomian negara sedang terpuruk akibat tingginya harga minyak dan menurunnya produk ekspor. Para investor diharapkan dapat membawa langsung dana segar (fresh money) dengan harapan agar modal yang masuk tersebut dapat menggerakkan roda perusahaan/industri yang pada gilirannya dapat menggerakkan perekonomian negara.

Kebijakan investasi di Indonesia pada dasarnya merujuk pada ketentuan pasal 33 UUD 1945. Esensialisasi pasal 33 UUD 1945 adalah perekonomian Indonesia berorientasi pada ekonomi kerakyatan. Hal itu merupakan penuangan yuridis konstitusional dari amanat yang dikandung di dalam pembukaan UUD 1945, yaitu mewujudkan kesejahteraan sosial bagi seluruh rakyat Indonesia. Di Indonesia kebijakan investasi ditegaskan melalui UU Nomor I Tahun 1967 (diubah dan ditambah dengan UU Nomor 11 Tahun 1970, tentang Undang Undang Penanaman Modal Asing (UUPMA)) dan UU Nomor 6 Tahun 1968 (diubah dan ditambah UU Nomor 12 Tahun 1970 tentang Undang Undang Penanaman Modal Dalam Negeri (UUPMDN)). Dan terakhir adalah Undang-Undang Nomor 25 tahun 2007 tentang Penanaman Modal Asing. Apabila dilihat latar belakang upaya modal asing masuk ke Indonesia jelas terkait dengan kepentingan dan kebutuhan akan modal untuk pembangunan ekonomi, khususnya melalui sektor industri.

Masuknya investasi ke Indonesia selain untuk untuk industri, sektor pariwisata juga sangat diminati. Saat ini di daerah pariwisata, banyak hotel, resort bahkan pulau yang diindikasikan sudah dibeli oleh Warga Negara Asing dengan mengatas namakan WNI. Departemen Kelautan dan Perikanan (DKP) menemukan indikasi terjadinya praktik jual-beli Pulau Bawah di perairan selatan Kabupaten Natuna Provinsi Kepulauan Riau (Kepri) kepada asing asal Australia dan Malaysia senilai Rp1 miliar. Pulau Bawah dan empat pulau kecil lainnya semula hanya menggunakan 51 lembar surat alas hak atas nama Muktar yang 
kemudian dijual dengan akta notaris di Tanjungpinang kepada Tasfinardi dan dilegalisir kepemilikannya oleh aparat Kepala Desa. Selain di Kepulauan Riau, jual beli pulau juga diindikasikan terjadi di Nusa Tenggara Barat.

Alasan dilakukannya hal tersebut karena para WNA menganggap jangka waktu Hak yang dapat dimiliki WNA tidak memadai terutama untuk berinvestasi, dengan membandingkan kondisi di negara tetangga yang memperbolehkan WNA memiliki tanah hingga 90 tahun. Sehingga banyak kalangan menyuarakan agar warga negara asing (orang asing) dapat mempunyai hak atas tanah di Indonesia dengan jangka waktu yang lebih lama dari jangka waktu yang diperbolehkan hukum pertanahan nasional saat ini. Argumen atau pertimbangan yang dikemukakan terutama supaya industri properti di Indonesia lebih maju pemasarannya, supaya diminati warga negara asing, seiring sejalan juga untuk mendongkrak gairah investasi industri property. Tuntutan ini juga diajukan oleh elemen masyarakat Kepuluan Riau khusunya Kota Batam menyuarakan hal senada, dengan dua alasan logis yakni: pertama, letak geografis Provinsi Kepulauan Riau yang bertetangga dengan Negara Singapore dan Malaysia dan berada pada jalur lalu lintas perdagangan internasional yang padat, dan kedua ditetapkannya Batam, Bintan dan Karimun (BBK) sebagai kawasan perdagangan bebas dan pelabuhan bebas yang lebih dikenal dengan FTZ BBK. Kedua hal tersebut merupakan fakta sebagai potensi membuka peluang besar bagi WNA berminat memiliki tanah dan bangunan di kawasan BBK. Dipihak lain justru dengan BBK sebagai FTZ sehingga perlu dipikirkan adanya kebijakan dibidang pertanahan yang bertujuan agar WNA dan badan hukum asing dapat memiliki hak atas tanah di kawasan BBK dengan jangka waktu yang lebih lama dari yang ada saat ini.

Terlepas dari berbagai tuntutan tersebut, fenomena yang sedang berkembang terutama di daerah industri dan pariwisata, harus segera diantisipasi mengingat era globalisasi saat ini memungkinkan terus meningkatnya orang-orang asing untuk berinvestasi dan menetap di Indonesia.

Menindak lanjuti kondisi tersebut di atas, maka perlu segera dilakukan penelitian untuk mengantisipasi kemungkinan yang terjadi akibat dari fenomena tersebut dan memberikan solusi yang terbaik bagi pembuat kebijakan dalam menghadapi masalah tersebut.

\subsection{Permasalahan}

Berdasarkan pada latar belakang tersebut di atas, maka rumusan masalah dalam penelitian ini adalah sebagai berikut:

1. Apakah BPN setempat sudah mengidentifikasi kasus penguasaan tanah oleh warga negara asing melalui pinjam nama ini ? 
2. Bagaimana mekanisme terjadinya penguasaan tanah oleh warga negara asing tersebut di atas?

3. Bagaimana sistem pengawasan dan pengendalian yang efektif ?

\subsection{Tujuan}

1. Memperoleh gambaran volume kasus yang ada

2. Mengetahui mekanisme terjadinya penguasaan tanah oleh warga negara asing..

3. Mengetahui sistem pengawasan dan pengendalian yang efektif

\subsection{Out Put}

Memberikan rekomendasi bagi pengambil kebijakan untuk membuat kebijakan yang komprehensif terhadap masalah ini karena masalah ini cukup kompleks tidak hanya menyangkut masalah hukum dan ekonomi, tetapi juga politik dan keamanan negara.

\section{BAB II}

\section{TINJAUAN PUSTAKA}

\subsection{Landasan Hukum Pemberian Hak Atas Tanah Kepada WNA}

Dalam UUPA, setiap Warga Negara Indonesia dapat memiliki tanah baik laki-laki maupun wanita mempunyai kesempatan yang sama untuk memperoleh sesuatu hak atas tanah serta untuk mendapat manfaat dan hasilnya, baik bagi diri sendiri maupun keluarganya. Adapun macam hak atas tanah yang dapat dkuasai oleh Warga Negara Indonesia, tercantum dalam pasal 16 ayat (1) UUPA antara lain : Hak Milik, Hak Guna Usaha, Hak Guna Bangunan, Hak Pakai, Hak Sewa, Hak Membuka Tanah, Hak Memungut Hasil Hutan, dan hak-hak lain yang tidak termasuk dalam hak-hak tersebut di atas. Dari bermacam hak di atas hanya Warga Negara Indonesia yang dapat mempunyai Hak Milik.

Terhadap Warga Negara Asing hanya boleh memiliki tanah dengan Hak Sewa dan Hak Pakai. Hak Pakai dapat terjadi karena pemberian oleh Negara(Pemerintah) maupun karena pemberian oleh pemegang Hak Milik.

Pemberian hak oleh Pemerintah ini berupa suatu penetapan atau keputusan (beschikking) oleh Pejabat yang berwenang berdasarkan suatu peraturan perundang-undangan. Pemberian oleh pemegang hak milik terjadi berdasarkan perjanjian antara si pemegang hak milik dengan warga Negara asing.

Hak Pakai diatur dalam pasal 41, 42 dan 43 UUPA yang bunyinya sebagai berikut :

\section{Pasal 41}

(1) Hak pakai adalah hak untuk menggunakan dan/atau memungut hasil dari tanah yang dikuasai langsung oleh Negara atau tanah milik orang lain, yang memberi wewenang dan kewajiban yang ditentukan dalam keputusan pemberiannya oleh pejabat yang berwenang memberikannya atau dalam perjanjian dengan pemilik tanahnya, yang bukan perjanjian 
sewa-menyewa atau perjanjian pengolahan tanah, segala sesuatu asal tidak bertentangan dengan jiwa dan ketentuan-ketentuan Undang-undang ini.

(2) Hak pakai dapat diberikan :

a. selama jangka waktu yang tertentu atau selama tanahnya dipergunakan untuk keperluan yang tertentu;

b. dengan cuma-cuma, dengan pembayaran atau pemberian jasa berupa apapun.

(3) Pemberian hak pakai tidak boleh disertai syarat-syarat yang mengandung unsur-unsur pemerasan.

\section{Pasal 42}

Yang dapat mempunyai hak pakai ialah :
a. warga negara Indonesia;
b. orang asing yang berkedudukan di Indonesia;
c. badan hukum yang didirikan menurut hukum Indonesia dan berkedudukan di Indonesia;
d. badan hukum asing yang mempunyai perwakilan di Indonesia.

\section{Pasal 43}

(1) Sepanjang mengenai tanah yang dikuasai oleh Negara maka hak pakai hanya dapat dilalihkan kepada pihak lain dengan izin pejabat yang berwenang.

(2) Hak pakai atas tanah milik hanya dapat dialihkan kepada pihak lain, jika hal itu dimungkinkan dalam perjanjian yang bersangkutan.

Menunjuk pada ketentuan Pasal 42 angka (2) UUPA, UU No. 16 Tahun 1985 tentang Rumah Susun mengatur bahwa orang asing hanya dapat memiliki satuan rumah susun (SRS) yang dibangun atas tanah hak pakai.

Ketentuan ini sejalan dengan konsep rumah susun (rusun) yang dianut oleh Indonesia berbeda dengan konsep rusun pada umumnya yang dikenal dengan strata title. Strata title memungkinkan seseorang memiliki SRS tanpa memiliki tanah bersama (tanah di bawah bangunan rusun). Sedangkan Indonesia memandang pemilik SRS adalah juga pemilik tanah bersama sehingga konsekuensinya, untuk orang asing, tanah bersama juga harus atas hak pakai.

Sebenarnya masalah tersebut sudah disinggung PP No. 41 Tahun 1996 tentang Pemilikan Rumah Tempat Tinggal atau Hunian oleh Orang Asing yang berkedudukan di Indonesia dan Peraturan Menteri Negara Agraria No. 7 tahun 1996 yang di ubah oleh Permen No. 8 tahun 1996 tentang Persyaratan Pemilikan Rumah Tempat Tinggal atau Hunian oleh Orang Asing.

Masalah fleksibilitas, (Arie : 2006) peraturan tanah Indonesia lebih ramah kepada orang asing dibanding Singapura, Australia, dan Malaysia. Pasal 1 PP No. 41 Tahun 1996 tidak mengharuskan orang asing untuk tinggal terus menerus di Indonesia selama 12 bulan berturutturut untuk membeli rumah di Indonesia dan tidak diharuskan beli langsung dari developer. 
Peraturan Menteri Negara Agraria No. 7 Tahun 1996, lebih lanjut lagi, hanya mensyaratkan orang asing tersebut harus memberi manfaat untuk pembangunan nasional.

Sedangkan di Singapura, orang asing yang diperbolehkan memiliki rumah diharuskan menetap di sana, setidaknya setahun terus menerus. Di Australia, orang asing hanya boleh membeli langsung dari developer, dan di Malaysia orang asing boleh membeli rumah tapi dengan pajak sebesar 35\% serta lewat KPR luar negeri. Karena itu, Prof Arie menyatakan Indonesia tidak perlu melihat ke luar terus karena memang dasarnya berbeda.

Dalam pandangannya, kesulitan warga asing selama ini sebenarnya disebabkan karena developer dan masyarakat yang kurang sosialisasi. Developer, biasanya takut kalau menggunakan hak pakai, orang Indonesia tidak mau beli. Sedangkan masyarakat beranggapan hak pakai lebih lemah dari pada HGB. "Padahal bedanya hanya lima tahun. Sisanya sama saja.

Menurut Arie Sukanti minimnya tanah dengan hak pakai melahirkan praktek penghindaran hukum (law-evading). Ada tiga cara yang paling lazim digunakan: sewa menyewa jangka panjang, convertible lease, dan nominee/trustee arrangement. Convertible lease dapat disamakan dengan beli sewa di Indonesia. Rumah atau SRS disewa jangka panjang dengan hak opsi membeli berdasarkan harapan suatu saat HGB akan diperbolehkan untuk orang asing. "Tapi sampai sekarang belum terlihat tanda-tanda ke arah itu," ujarnya.

Konsep nominee/trustee arrangement sebenarnya tidak dikenal dalam sistem hukum Indonesia. "Dasarnya ya kebebasan berkontrak". Metode ini mengharuskan orang asing membentuk sebuah badan hukum Indonesia yang akan membeli SRS dari developer. Orang asing tersebut, nantinya seolah-olah akan memberikan sejumlah kredit dengan jaminan SRS tersebut. Nantinya, badan hukum tersebut akan memberikan seluruh hak sebagai penghuni SRS dengan pemberian kuasa kepada si orang asing sementara hak miliknya tetap berada di tangan si badan hukum.

Menurut Peraturan Pemerintah (PP) No. 41 tahun 1996 yang mengatur tentang Pemilikan Rumah Tinggal atau Hunian oleh Orang Asing (WNA). Isinya antara lain:

1. WNA yang berkedudukan di Indonesia diperkenankan memiliki satu rumah tinggal (bisa sarusun) yang dibangun di atas hak pakai.

2. Rumah yang berdiri di atas Hak Pakai atas Tanah Negara (HPTN) atau Hak Pakai yang berasal dari tanah Hak Milik yang diberikan oleh pemegang Hak Milik dengan akta PPAT dan perjanjiannya harus dicatat dalam buku tanah dan sertipikat Hak Milik.

Lebih lanjut PP No. 41 tahun 1996 tentang Pemilikan Rumah Tempat Tinggal Atau Hunian Oleh Orang Asing Yang Berkedudukan Di Indonesia.

\section{Pasal 1}

(1) Orang asing yang berkedudukan di Indonesia dapat memiliki sebuah rumah untuk tempat tinggal atau hunian dengan hak atas tanah tertentu. 
(2) Orang asing yang berkedudukan di Indonesia sebagaimana dimaksud dalam ayat (1) adalah orang asing yang kehadirannya di Indonesia memberikan manfaat bagi pembangunan nasional.

\section{Pasal 2}

Rumah tempat tinggal atau hunian yang dapat dimiliki oleh orang asing sebagaimana dimaksud dalam Pasal 1 adalah:

1. Rumah yang berdiri sendiri yang dibangun di atas bidang tanah:

a. Hak Pakai atas tanah Negara;

b. Yang dikuasai berdasarkan perjanjian dengan pemengang hak atas tanah.

2. Satuan rumah susun yang dibangun di atas bidang tanah Hak Pakai atas tanah Negara.

\section{Pasal 3}

(1) Perjanjian sebagaimana dimaksud dalam Pasal 2 angka 1 dibuat secara tertulis antara orang asing yang bersangkutan dengan pemegang hak atas tanah.

(2) Perjanjian tertulis sebagaimana dimaksud dalam ayat (1) harus dibuat dengan akta Pejabat Pembuat Akta Tanah.

\section{Pasal 4}

Perjanjian sebagaimana dimaksud dalam Pasal 2 angka 1 wajib dicatat dalam buku tanah dan sertipikat hak atas tanah yang bersangkutan.

\section{Pasal 5}

(1) Perjanjian sebagaimana dimaksud dalam Pasal 2 angka 1 dibuat untuk jangka waktu yang disepakati, tetapi tidak lebih lama dari dua puluh lima tahun.

(2) Jangka waktu sebagaimana dimaksud dalam ayat (1) dapat diperbaharui untuk jangka waktu yang tidak lebih lama dari dua puluh lima tahun, atas dasar kesepakatan yang dituangkan dalam perjanjian yang baru, sepanjang orang asing tersebut masih berkedudukan di Indonesia.

\section{Pasal 6}

(1) Apabila orang asing yang memiliki rumah yang dibangun di atas tanah Hak Pakai atas tanah Negara, atau berdasarkan perjanjian dengan pemegang hak atas tanah tidak lagi berkedudukan di Indonesia, maka dalam jangka waktu satu tahun wajib melepaskan atau mengalihkan hak atas rumah dan tanahnya kepada orang lain yang memenuhi syarat.

(2) Apabila dalam jangka waktu sebagaimana dimaksud dalam ayat (1) hak atas tanah tersebut belum dilepaskan atau dialihkan kepada pihak lain yang memenuhi syarat, maka apabila:

a. Rumah tersebut dibangun di atas tanah Hak Pakai atas tanah Negara, rumah beserta tanahnya dikuasai Negara untuk dilelang;

b. Rumah tersebut dibangun di atas tanah berdasarkan perjanjian sebagaimana dimaksud dalam Pasal 2 angka 1 huruf $b$, rumah tersebut menjadi milik pemegang hak atas tanah yang bersangkutan. 
Berdasarkan ketentuan Peraturan Pemerintah No. 41 Tahun 1996, misalnya jaminan hak tanggungan di lembaga perbankan tidak dipersulit bila tanah yang dianggunkan adalah tanah dengan status Hak Pakai. Upaya-upaya ini seyogyanya dilakukan secara komprehensif dan berkesinambungan, tanpa mengenyampingkan undang-undang lain yang mengatur tentang kewajiban seorang WNI atau badan hukum dalam kepemilikan tanah.

Ketentuan yang menyangkut sewa menyewa dalam UUPA :

\section{Pasal 44}

(1) Seseorang atau suatu badan hukum mempunyai hak sewa atas tanah, apabila ia berhak mempergunakan tanah milik orang lain untuk keperluan bangunan dengan membayar kepada pemiliknya sejumlah uang sebagai sewa.

(2) Pembayaran uang sewa dapat dilakukan :

a. satu kali atau pada tiap-tiap waktu tertentu;

b. sebelum atau sesudah tanahnya dipergunakan.

(3) Perjanjian sewa tanah yang dimaksudkan dalam pasal ini tidak boleh disertai syaratsyarat yang mengandung unsur-unsur pemerasan.

\section{Pasal 45}

Yang dapat menjadi pemegang hak sewa ialah :
a. warganegara Indonesia;
b. orang asing yang berkedudukan di Indonesia;
c. badan hukum yang didirikan menurut hukum Indonesia dan berkedudukan di Indonesia;
d. badan hukum asing yang mempunyai perwakilan di Indonesia.

Dalam Peraturan Pelaksanaan PP Nomor 41 tahun 1996 yaitru PMNA/Ka.BPN Nomor 7 tahun 1996 menyebutkan :

\section{Pasal 1}

(1) Orang asing yang kehadirannya di Indonesia memberi manfaat bagi pembangunan nasional dapat memiliki sebuah rumah tempat tinggal atau hunian dalam bentuk rumah dengan hak atas tanah tertentu atau satuan rumah susun yang dibangun di atas tanah Hak Pakai atas tanah Negara.

(2) Orang asing sebagaimana dimaksud dalam ayat (1) adalah orang asing yang memiliki dan memelihara kepentingan ekonomi di Indonesia dengan melaksanakan investasi untuk memiliki rumah tempat tinggal atau hunian di Indonesia

\section{Pasal 2}

(1) Pemilikan rumah dan cara perolehan hak atas tanah oleh orang asing dapat dilakukan dengan:

a. Membeli atau membangun rumah di atas tanah dengan Hak Pakai atas tanah Negara atau Hak Pakai atas tanah Hak Milik; 
b. Membeli satuan rumah susun yang dibangun di atas tanah Hak Pakai atas tanah Negara;

c. Membeli atau membangun rumah di atas tanah Hak Milik atau Hak Sewa untuk Bangunan atas dasar perjanjian tertulis dengan pemilik hak atas tanah yang bersangkutan.

(2) Rumah yang dapat dibangun atau dibeli dan satuan rumah susun yang dapat dibeli oleh orang asing dengan hak atas tanah sebagaimana dimaksud dalam ayat (1) adalah rumah atau satuan rumah susun yang tidak termasuk klasifikasi rumah sederhana atau rumah sangat sederhana.

(3) Perolehan hak atas tanah dan/atau rumah atau Hak Milik atas Satuan Rumah Susun, pemberian Hak Pakai atas tanah Hak Milik, dan pemberian Hak Sewa untuk Bangunan sebagaimana dimaksud pada ayat (1) dilakukan menurut tata cara sesuai ketentuan peraturan perundang-undangan yang berlaku untuk perbuatan hukum yang bersangkutan.

\section{Pasal 3}

Selama tidak dipergunakan oleh pemiliknya rumah tersebut dapat disewakan melalui perusahaan di Indonesia berdasarkan perjanjian antara orang asing pemilik rumah dengan perusahaan tersebut.

\section{Pasal 4}

Orang asing yang telah memiliki rumah di Indonesia tidak lagi memenuhi syarat berkedudukan di Indonesia sebagaimana dimaksud dalam Pasal 6 ayat (1) Peraturan Pemerintah Nomor 41 Tahun 1996 apabila yang bersangkutan atau keluarganya tidak menggunakan rumah tersebut selama jangka waktu 12 (dua belas) bulan berturut-turut.

\subsection{Perolehan Hak Karena Perjanjian}

a) Kitab Undang Undang Hukum Perdata Pasal 1320, dan 1338

Pasal 1320 KUH Perdata menentukan empat syarat sahnya perjanjian yaitu harus ada kesepakatan, kecakapan, hal tertentu dan sebab yang diperbolehkan.

Berlakunya asas kebebasan berkontrak dijamin oleh oleh Pasal 1338 ayat (1) KUH Perdata, yang menentukan bahwa :

"setiap perjanjian yang dibuat secara sah berlaku sebagai undang-undang bagi mereka yang membuatnya".

b) Convention on Contracts on International Sales of Goods (1980) perjanjian internasional

Dalam konteks separate yang dimaksud di atas, perjanjian internasional dibedakan ke dalam dua golongan, yaitu: "law making treaties" dan "treaty contracts"."Law making treaties", adalah perjanjian internasional yang mengandung kaidah-kaidah hokum yang dapat berlaku secara universal bagi anggota masyarakat bangsa-bangsa; sehingga dengan 
demikian dikategorikan sebagai perjanjian-perjanjian internasional yang berfungsi sebagai sumber langsung hukum internasional. Sedangkan perjanjian internasional yang digolongkan sebagai "treaty contracts" mengandung ketentuan-ketentuan yang mengatur hubungan-hubungan atau persoalan-persoalan khusus antara pihak yang mengadakannya saja, sehingga hanya berlaku khusus bagi para peserta perjanjian. Oleh sebab itu perjanjian-perjanjian internasional yang tergolong treaty contracts tidak secara langsung menjadi sumber hukum internasional.

Kecenderungan semakin pentingnya perjanjian internasional dalam mengatur berbagai persoalan, ternyata tidak hanya berlangsung dalam bidang hukum publik internasional, melainkan juga berlangsung dalam bidang hokum perdata internasional (HPI). Ini ditunjukan umpamanya oleh upaya yang dilakukan sejumlah negara sejak akhir abad ke 19 melalui penyelenggaraan beberapa konperensi dalam bidang HPI yang diselenggarakan di Den Haag, yang antara lain bertujuan untuk mempersiapkan unifikasi kaidah-kaidah HPI. Seperti diketahui, setiap negara merdeka dan berdaulat memiliki system HPI-nya sendiri-sendiri, sehingga norma HPI setiap negara itu tidak sama. Untuk mengatasi kesulitan yang timbul dalam hal terjadi persoalan yang melibatkan dua negara atau lebih, negara-negara mengadakan upaya kerjasama internasional dengan jalan mempersiapkan konvensi-konvensi yang bertujuan terciptanya unifikasi di dalam bidang hukum, khususnya hukum perdata. Akan tetapi upaya yang dilakukan itu bukan bermaksud untuk melakukan penyeragaman seluruh sistem hokum intern dari negaranegara peserta konperensi, melainkan hanya berusaha melakukan penyeragaman atas kaidah-kaidah HPI. Dengan demikian diharapkan untuk masalah-masalah hukum perdata tertentu akan dapat dicapai kesatuan dalam penyelesaian persoalan oleh badan-badan peradilan masing-masing negara peserta.

\subsection{Sejarah Penguasaan Tanah Oleh Warga Negara Asing}

\section{A. Masa Feodalisme}

Pada masa abad 18 dan awal 19, secara umum di Jawa dikenal 3 kelas penguasaan tanah, yaitu:

(1) Kelompok besar petani tuna-kisma yang kadangkala berlindung pada keluargakeluarga petani yang memiliki tanah, namunjuga sering merupakan kelompok tenaga kerja musiman yang tidak terikat dan cukup mobil. Secara kuantitas jumlah petani tuna-kisma ini cukup besar dan menjadi kelompok inti kegiatan pertanian.

(2) Kelompok mayoritas petani (sikep atau kuli) yang memiliki hak atas tanah, dan untuk hak tersebut berkewajiban membayar pajak dan upeti yang besar jumlahnya kepada pihak kerajaan. 
(3) Kelas pamong desa yang selain menguasai tanah pribadi, juga berhak menguasai sejumlah besar tanah desa sebagai upah mereka dalam mengatur pemerintahan (lungguh dan tanah bengkok), ditambah lagi hak memperkejakan sikep atau kuli untuk mengarap tanah mereka tersebut tanpa membayar upah.

Menurut van de Kroef (1984), terdapat beragam bentuk penguasaan antar daerah di Jawa, dan penguasan individual dan juga kolektif ada pada satu daerah secara bersamaan. Pola penguasaan tanah cenderung berada di antara dua kutub yang berlawanan, yaitu pemilikan komunal yang kuat atau hak ulayat, dan pemilikan perorangan dengan beberapa hak istimewa komunal.

Hak penguasaan tanah ada pada kerajaan, sehingga petani hanyalah berstatus sebagai penggarap, maka perolehan bagi petani sangat terbatas. Akibatnya, seperti yang dilihat banyak ahli, komersialisasi pedesaan tidak berjalan, dan investasi pertanian mandeg. Penguasaan tanah oleh kerajaan, menjadi alat politik pihak kerajaan, agar dapat mengontrol seluruh warga dan terutama pembantu-pembantunya di level desa. Kepatuhan dari pembantu di tingkat desa terbentuk melalui pemberian tanah lungguh kepada mereka yang sewaktu-waktu dapat dicabut oleh pihak kerajaan.

\section{B. Masa Pemerintahan Kolonial}

Pemerintah Belanda mengeluarkan Undang-Undang Agararia tahun 1870 (Agrarische Wet). Undang- undang ini memberi kesempatan kepada penyewaan jangka panjang tanahtanah untuk perkebunan. Peraturan ini menjadi dasar peraturan agraria di Indonesia, namun bersifat dualistis, karena bagi orang asing berlaku hukum Barat, dan bagi rakyat Indonesia berlaku hukum adat. Disini dimungkinkan untuk memiliki mutlak (hak eigendom) termasuk hak untuk menyewakannya ke pihak lain.

Tujuan UU ini adalah untuk memberikan kesempatan luas bagi modal swasta asing yang memang berhasil. Tetapi tujuan lainnya, yaitu melindungi dan memperkuat hak atas tanah bagi bangsa Indonesia asli ternyata jauh dari harapan (Wiradi, 2000).

Pemerintah kolonial telah memilih pola penguasaan atas tanah, disewa atau dengan pajak, sebagai instrumen yang penting dalam memajukan pertanian, meskipun ini bersifat sepihak yaitu untuk kepentingan dirinya saja. Politik agraria Belanda memberikan dampak yang hampir serupa bagi petani dibandingkan dengan politik agraria kerajaan, karena meskipun pada tingkat atas kerajaan digantikan oleh Belanda, namun struktur masyarakat pada tingkat bawah (desa) masih tetap sama. Petani tetaplah seorang penggarap dengan kewajiban menyerahkan sebagian hasilnya kepada pihak penguasa.

\section{Masa Kemerdekaan (Orde Lama dan Orde Baru)}

Masa Orde Lama ditandai dengan kelahiran Undang-Undang Pokok Agraria No. 5 
tahun 1960. Dalam proses pembuatan produk hukum ini terlihat bahwa pemerintah memberi perhatian serius terhadap pentingnya permasalahan agraria sebagai landasan pokok dalam pembangunan pertanian dan pedesaan (Wiradi, 2000). Menurut Fauzi (1999), kebijakan hukum dalam UUPA ini sesungguhnya menentang kapitalisme yang melahirkan kolonialisme yang menyebabkan penghisapan manusia atas manusia.

Politik agraria yang terkandung dalam UUPA 1960 adalah politik populisme, yang mengakui hak individu atas tanah, namun hak tersebut memiliki "fungsi sosial". Melalui prinsip Hak Menguasai dari negara, pemerintah mengatur agar tanah-tanah dapat dipergunakan sebesar-besarnya untuk kemakmuran rakyat sebagaimana termaktub dalam pasal 33 UUD 1945.

Pemerintah Orde Baru yang sangat terinpirasi dengan kemajuan ekonomi, menjadikan tanah sebagai alat pembangunan yang sentralistis, sehingga menimbulkan berbagai konflik dengan masyarakat. Hal ini misalnya, karena pemerintah hanya mengejar industrialisasi pertanian, tidak memperhatikan sama sekali aspek struktur penguasaan tanah. Pemerintah meneruskan program pembangunan perkebunan-perkebunan berskala besar dengan tanah-tanah yang luas, namun kurang memperdulikan semakin banyaknya jumlah petani yang tidak bertanah dan sangat membutuhkannya.

Secara umum dapat dikatakan, telah terjadi perubahan pola penguasaan dari komunal ke penguasaan individual semenjak zaman pra kolonial sampai Orde Baru. Hal ini terlihat dari semakin hilangnya tanah-tanah hak ulayat digantikan bentuk penguasaan "milik" privat, sehingga dapat disewakan dan diperjualbelikan. Sebelumnya hanya dikenal pemilikan individual terbatas, yaitu tanah komunal yang meskipun dapat dikelola secara terus menerus oleh satu keluarga dan boleh diwariskan, namun tidak dapat disewakan apalagi diperjual belikan. Jenis pemilikan seperti ini disebut juga dengan "pemilikan komunal yang berciri privat".

Dalam penelitian Amaluddin (1987) di Kendal Jawa Tengah untuk memahami kondisi pada zaman Orde Lama, perubahan sistem penguasaan tanah juga telah menyebabkan perubahan sistem produksi pertanian. Sebelum tahun 1960, ada tiga jenis hak penguasaan tanah komunal, yaitu hak bengkok, hak banda desa, hak narawita, serta satu yang bersifat individual yaitu hak yasan tanah yasan mencakup 76,7 persen dari total tanah di desa tersebut. Penerapan UUPA tahun 1960 menyebabkan konversi tanah yang semula berdasarkan hukum adat (komunal) menjadi hak milik. Hak narawita, secara de facto sudah menjadi milik individual, sehingga penjualan tanah berkembang, peluang tunakisma untuk menggarap mengecil, dan mobilitas penguasaan cenderung sentrifugal atau terpolarisasi. Bersamaan dengan itu, sistem produksi yang semula dilandasi nilai-nilai tradisional digantikan oleh sistem produksi komersial.

Pemberian hak atas tanah kepada WNA telah diatur dalam UUPA. UUPA menentukan bahwa hanya WNI yang dapat menjadi subyek Hak Milik, bagi WNA dimungkinkan untuk 
diberikan HP. Dengan demikian pemberian HP kepada WNA merupakan salah satu kebijakan publik. Oleh karena itu, maka perlu terlebih dahulu dikaji mengenai kebijakan publik. Winarno (2007) mendefinisikan kebijakan publik sebagai arah tindakan yang dilakukan oleh pemerintah yang area studinya meliputi segala tindakan yang dilakukan oleh pemerintah dan mempunyai pengaruh terhadap kepentingan masyarakat secara luas. Selanjutnya, Dwijowijoto (2003) menambahkan bahwa kebijakan publik merupakan kebijakan yang dibuat oleh organisasi publik, yaitu lembaga legislatif dan yudikatif.

Berdasarkan hal tersebut di atas, jelaslah bahwa pemberian HP kepada WNA merupakan salah satu kebijakan publik. Hal ini disebabkan karena kebijakan pemberian hak atas tanah kepada WNA telah dituangkan dalam peraturan perundang-undangan, yakni Undang-Undang Nomor 5 tahun 1960 sebagai produk bersama antara legislatif dan eksekutif. Selanjutnya sebagai turunannya, telah diterbitkan pula PP Nomor 40 Tahun 1996 dan PP Nomor 41 Tahun 1996 sebagai produk eksekutif.

Kebijakan tersebut bertujuan untuk memberikan kepastian hukum bagi WNA yang menguasai tanah di Indonesia. Sebagai suatu kebijakan publik, maka yang terpenting adalah implementasinya. Udoji dalam Solichin Wahab (1997) bahkan menyatakan bahwa pelaksanaan kebijakan jauh lebih penting daripada pembuatan kebijakan itu sendiri. Oleh karena itu, aparat pelaksana diharapkan dapat menerjemahkan kebijakan itu ke dalam tindakan yang nyata walaupun pelaksanaan kebijakan apapun sebenarnya mengandung risiko kegagalan.

Berdasarkan uraian tersebut di atas dan fakta di lapangan, terdapat indikasi bahwa kebijakan pemberian HP kepada WNA tidak dapat dilaksanakan secara efektif, khususnya di Provinsi Bali (Hutagalung, 2000). Sebagai contoh, Hutagalung (2000) mengatakan bahwa terdapat seorang WNA merencanakan membuat perjanjian pelepasan hak dengan pemilik tanah yang berstatus Hak Milik, namun diperoleh keterangan dari kantor pertanahan bahwa permohonan tersebut tidak dapat dilaksanakan karena belum ada peraturan daerah yang mengatur hal tersebut. Hal ini menandakan bahwa aparat pertanahan cenderung bertindak hatihati karena pemberian hak atas tanah senantiasa menjadi satu-kesatuan dengan pemanfaatan tanahnya. Aparat pertanahan tampaknya menginginkan adanya pengaturan yang jelas mengenai pemanfaatan tanah oleh WNA, yang paling tidak dalam bentuk peraturan daerah.

Gautama dan Soetiyarto (1996) menyatakan bahwa HP kepada WNA dapat diberikan di atas tanah negara, tanah hak pengelolaan, dan tanah hak milik. Selanjutnya, Nasution (2000) menyatakan bahwa apabila karena sesuatu dan lain hal Pemerintah Daerah Provinsi Bali dan jajarannya tidak berkenan memasyarakatkan pemberian HP di atas tanah negara, maka sesuai dengan Pasal 44 PP Nomor 40 Tahun 1996 dan Pasal 2 PP Nomor 41 Tahun 1996, berdasarkan perjanjian dengan pemegang haknya dapat ditempuh melalui pemberian HP di atas tanah Hak Pengelolaan atau Hak Milik. 
Pemberian HP di atas tanah hak milik memang sangat memungkinkan. Hal ini karena hak milik merupakan hak turun temurun, terkuat, dan terpenuh yang dapat dipunyai orang atas tanah dan termasuk hak primer. Dengan demikian hak milik dapat dibebani dengan hak atas tanah yang lain seperti HP. UUPA menegaskan bahwa HP adalah hak untuk menggunakan dan/atau memungut hasil dari tanah yang dikuasai langsung oleh Negara atau tanah milik orang lain, yang memberi wewenang dan kewajiban yang ditentukan dalam keputusan pemberiannya oleh pejabat yang berwenang memberikannya, atau dalam perjanjian dengan pemilik tanahnya, yang bukan perjanjian sewa menyewa atau perjanjian pengolahan tanah, segala sesuatu asal tidak bertentangan dengan jiwa dan ketentuan UUPA. Berdasarkan pengertian tersebut, maka HP di atas tanah hak milik mengandung pengertian sebagai hak untuk menggunakan dan/atau memungut hasil dari tanah milik orang lain, yang memberi wewenang dan kewajiban yang ditentukan dalam perjanjian dengan pemilik tanahnya.

Sampai saat ini solusi sebagaimana disebutkan di atas terindikasi belum dilaksanakan. Utama (2006) mengatakan bahwa alasan WNA tidak mematuhi kebijakan pemberian HP sebagaimana ditentukan dalam peraturan perundang-undangan kemungkinan disebabkan oleh birokrasi yang berbelit-belit, tindakan sewenang-wenang oleh pejabat yang terkait, adanya pungutan liar, dan adanya peraturan perundang-undangan yang mengandung norma kabur.

Berdasarkan hal tersebut, ditinjau dari kebijakan publik, kegagalan implementasi kebijakan pemberian HP kepada WNA disebabkan karena faktor peraturannya, pelaksananya, dan perilaku masyarakatnya. Pengaturan mengenai pemberian HP kepada WNA masih

membutuhkan dukungan pengaturan pemanfaatan tanah seperti peraturan daerah. Aparat pelaksana juga diindikasikan tidak melakukan upaya yang optimal agar kebijakan tersebut dapat dilaksanakan. Sementara itu, di sisi lain, masyarakat juga tidak berupaya mematuhi kebijakan itu, melainkan melakukan upaya-upaya yang sesungguhnya dilarang oleh Undang-undang. Upaya yang bertentangan ini telah terbangun dan menjadi tradisi yang berkembang di masyarakat sehingga perlu mendapatkan perhatian dari pemerintah.

\subsection{Bentuk-bentuk perjanjian dalam penguasaan dan Pemanfaatan tanah oleh WNA}

\section{A. Pinjam Nama}

Sebagaimana telah disebutkan di atas bahwa pemerintah telah mengeluarkan kebijakan pemberian HP kepada WNA. Namun kenyataan di lapangan terdapat indikasi bahwa kebijakan ini belum dapat dilaksanakan secara efektif (Hutagalung, 2000). Dalam praktik, minat WNA untuk memiliki tanah dengan status HP sangat rendah. Hal ini karena HP merupakan hak atas tanah yang lebih terbatas dibandingkan dengan hak atas tanah yang lain. Untuk itulah WNA cenderung berusaha untuk memiliki tanah dengan status Hak Milik yang sebenarnya dilarang oleh UUPA. 
Sanusi (2002) mengemukakan bahwa cara yang lazim digunakan oleh WNA dalam memperoleh Hak Milik atas tanah adalah dengan melakukan pernikahan di bawah tangan dengan seorang WNI, sehingga diperoleh Hak Milik atas nama suami/istri yang berstatus WNI. Sedangkan Kallo (2000) mengemukakan bahwa sering dijumpai WNA memiliki tanah Hak Milik dengan meminjam nama seorang WNI yang dapat dipercaya. Hal ini dipertegas oleh Sumardjono (2005) yang menyatakan bahwa WNA memiliki hak atas tanah dengan cara menggunakan "kedok", melakukan jual beli atas nama WNI, sehingga secara yuridis formal tidak menyalahi peraturan. Namun di samping itu, dilakukan upaya pembuatan perjanjian antara WNI dan WNA tersebut dengan cara pemberian kuasa (sering disebut dengan istilah Kuasa Mutlak), yang memberikan hak yang tidak dapat ditarik kembali oleh pemberi kuasa (WNI) dan memberikan kewenangan bagi penerima kuasa (WNA) untuk melakukan segala perbuatan hukum berkenaan dengan hak atas tanah tersebut yang menurut hukum hanya dapat dilakukan oleh pemegang hak (WNI) sehingga pada hakikatnya merupakan pemindahan hak atas tanah.

\section{B. Model Kontrak/Sewa Tanah}

Selain praktek pinjam nama yang dilakukan oleh WNA, Sumardjono (2005) mengatakan bahwa WNA juga sering melakukan praktek pemindahan hak melalui sewa. Konstruksi yuridis untuk menyerahkan Hak Milik kepada WNA dengan hak sewa untuk bangunan atau Hak Pakai adalah karena adanya asas pemisahan horizontal yang dianut oleh Hukum Tanah Nasional, yang berarti bahwa pada prinsipnya pemilikan bangunan terpisah dengan penguasaan tanahnya kecuali jika menurut kenyataan pemilikan bangunan dan penguasaan hak atas tanahnya berada pada satu tangan. Hal ini memang logis dan secara yuridis tidak menimbulkan masalah bila terjadi antara sesama WNI. Namun, bila hal ini diterapkan pada WNA, secara yuridis tidak dapat dipertanggungjawabkan, karena bertentangan dengan undang-undang, yakni melanggar larangan dalam Pasal 26 Ayat (2) UUPA berkenaan dengan pemindahan hak.

Sepintas lalu memang secara yuridis hal tersebut di atas memang tidak merupakan pemindahan hak (melalui jual beli), namun secara substansial hal ini merupakan pemindahan hak secara tidak langsung. Sebagai indikasi adanya pemindahan hak secara terselubung itu, misalnya dapat terjadi hal-hal sebagai berikut: a. uang sewa dibayar sekaligus atau uang pengganti untuk menyerahkan HP besarnya kurang lebih sama dengan harga tanah itu; b. jangka waktu perjanjian melampui batas kewajaran; c. pemilik hanya dapat meminta kembali tanahnya dengan membayar kembali sebesar harga tanah yang sebenarnya; dan lain-lain. Hal tersebut menunjukkan bahwa secara materiil sebenarnya telah terjadi pemindahan hak milik secara terselubung.

\section{Build Operate Transfer (BOT)}

Dewasa ini keperluan untuk pengadaan proyek infrastruktur, terutama di negara-negara Asia, mengalami peningkatan yang cukup banyak, akan tetapi kebanyakan pemerintah yang ada tidak dapat menyediakan dana yang diperlukan untuk mengadakan fasilitas infrastruktur tersebut sehingga perlu diadakan kerjasama antara pihak swasta dan pihak publik. 
Bagi pemerintahan yang tidak memiliki sumber keuangan yang cukup untuk membangun infrastruktur harus mencari alternatif terbaik untuk nemenuhi kebutuhan masyarakatnya. Salah satu alternatif yang sering digunakan adalah penggunaan pola BOT ( Build Operate Transfer ). Pola BOT dikenal luas di dunia, sebagai salah satu jalan keluar bagi permasalahan dana dalam membangun nfrastruktur, seperti sarana keperluan umum, peningkatan fasilitas umum, ransportasi, telekomunikasi dan listrik. Terdapat berbagai variasi atau istilah BOT yang dikenal luas, diantaranya : FBOOT (Finance Build Own Operate Transfer), B0L (Build Operate Lease), DBOM (Design Build Operate Maintain), BOT Build Operate Transfer), dan sebagainya. Istilah BOT digunakan untuk semua tipe Concession Agreement.

Build-operate-transfer (BOT) adalah sebuah bentuk pembiayaan proyek, di mana sebuah badan swasta yang menerima konsesi/ kesepakatan dari swasta maupun sektor publik untuk pembiayaan, desain, membangun, dan mengoperasikan fasilitas yang diatur dalam kontrak konsesi. Hal ini memungkinkan bagi pemegang/pelaksana proyek untuk mengembalikan investasi, biaya operasi dan pemeliharaannya dalam proyek.

Mengingat perjanjiannya yang bersifat jangka panjang, Biasanya biayanya dinaikkan selama periode konsesi atau kesepakatan. Tingkat kenaikan biasanya bersaing dengan kombinasi dari variabel internal dan eksternal, memungkinkan bagi pelaksana untuk mencapai kepuasan internal rate of retuen untuk investasinya.Biasanya, proyek-proyek tersebut menyediakan agar infrastruktur dapat di transfer untuk pemerintah pada akhir masa konsesi. (Di Australia, terutama untuk alasan yang terkait dengan peminjaman kekuasaan negara, kewajiban untuk transfer dapat dikesampingkan).

BOT adalah sebuah jenis proyek pembiayaan. Karakteristik dari proyek pembiayaan adalah:

(i) Debitur untuk proyek perhatian utamanya terletak pada penghasilan dari proyek yang menjadi sumber bagi pembayaran ulang pinjaman yang akan digunakan. penilaian kredit mereka didasarkan pada proyek, bukan pada kelayakan pinjaman dari perusahaan peminjam.

(ii) Tindakan pengamanan yang dilakukan oleh debitur sangat terbatas kepada aset- aset proyek tersebut. Karena itu, pembiayaan proyek sering disebut sebagai pembiayaan "limited resource" karena debitur hanya diberikan sumber dana terbatas bantuan bagi peminjam.

Sebagian besar struktur proyek pembiayaan sangat kompleks. Resiko dalam proyek yang tersebar antara berbagai pihak; setiap risiko biasanya dianggap oleh pihak yang paling efisien dan efektif-biaya kontrol atau menangani itu 
Pertimbangan-pertimbangan pokok bagi pembangunan proyek infrastruktur dengan pola BOT yang didasarkan atas kepentingan Pemerintah, khususnya Negara Berkembang adalah :

1. Tidak membebani neraca pembayaran pemerintah (off balance-sheet financing).

2. Mengurangi jumlah pinjaman Pemerintah maupun sektor publik lainnya;

3. Merupakan tambahan sumber pembiayaan bagi proyek-proyek yang diprioritaskan ( additional finance sources for priority projects );

4. Tambahan fasilitas baru;

5. Mengalihkan resiko bagi konstruksi, pembiayaan dan pengoperasian kepada sektor swasta;

6. Mengoptimalkan kemungkinan pemanfaatan perusahaan swasta maupun teknologi asing;

7. Mendorong proses alih teknologi, khususnya bagi kepentingan negara $\neg$ negara berkembang;

8. Diperolehnya fasilitas yang lengkap dan operasional setelah masa akhir konsesi.

\subsection{Faktor Pendorong terjadinya penguasaan dan pemanfaatan tanah oleh WNA}

\section{A. Faktor Yuridis}

Dalam hubungannya dengan perikatan antara WNA dengan penduduk lokal, Pasal 1338 Burgerlijk Wetbook, menyatakan bahwa semua persetujuan yang dibuat secara sah berlaku sebagai Undang-Undang bagi mereka yang membuatnya. Persetujuan-persetujuan itu tidak dapat ditarik kembali selain dengan sepakat kedua belah pihak atau karena alasan-alasan yang oleh Undang-undang dinyatakan cukup untuk itu. Persetujuan-persetujuan harus dilaksanakan dengan itikad baik.

Perjanjian menurut Pasal 1313 Kitab Undang-undang Hukum Perdata (selanjutnya disingkat KUHPdt) adalah suatu perbuatan dengan mana satu orang atau lebih mengikatkan dirinya terhadap satu orang atau lebih lainnya. Apabila diperinci perjanjian mengandung unsurunsur sebagai berikut:

a. ada pihak-pihak, sedikit-dikitnya dua orang (subyek);

b. ada persetujuan antara pihak-pihak itu (subyek);

c. ada obyek yang berupa benda;

d. ada tujuan yang bersifat kebendaan (mengenai harta kekayaan);

e. ada bentuk tertentu, lisan atau tulisan.

Salah satu asas dalam perjanjian adalah asas kebebasan berkontrak. Asas ini mengandung arti bahwa setiap orang bebas mengadakan perjanjian apa saja, baik yang sudah diatur atau belum diatur dalam Undang-undang. Tetapi kebebasan tersebut dibatasi oleh tiga hal, yaitu tidak dilarang oleh Undang-undang, tidak bertentangan dengan ketertiban umum, dan tidak bertentangan dengan kesusilaan. 
Selain itu, menurut ketentuan Pasal 1320 KUHPdt, syarat-syarat sahnya suatu perjanjian yaitu:

a. ada persetujuan kehendak antara pihak-pihak yang membuat perjanjian (konsensus);

b. ada kecakapan pihak-pihak untuk membuat perjanjian (capacity)

c. ada suatu hal tertentu (obyek);

d. ada suatu sebab yang halal (causa).

Menurut Abdul Kadir Muhammad syarat pertama dan kedua disebut syarat subyektif, karena melekat pada diri orang yang menjadi subyek perjanjian. Jika syarat ini tidak dipenuhi, maka perjanjian dapat dibatalkan. Sedangkan persyaratan ketiga dan keempat disebut syarat obyektif karena mengenai sesuatu yang menjadi obyek perjanjian. Jika syarat ini tidak dipenuhi, maka perjanjian batal. Batalnya perjanjian ini dapat diketahui apabila perjanjian tidak mencapai tujuan karena salah satu pihak tidak memenuhi kewajibannya. Kemudian diperkarakan di muka Hakim dan Hakim menyatakan perjanjian batal, karena tidak memenuhi syarat obyektif (Muhammad, 1993).

Berdasarkan hukum perikatan di atas, Sumardjono (2007) mengatakan bahwa perjanjian notariil yang dibuat antara WNI dengan WNA pada penguasaan tanah adalah tidak sah. Walaupun para pihak sepakat mengenai isi perjanjian itu. Perjanjian dengan penggunaan kuasa semacam itu, dengan menggunakan pihak WNI sebagai trustee atau nominee merupakan penyelundupan hukum karena substansinya bertentangan dengan UUPA, khususnya Pasal 26 Ayat (2) UUPA yang berbunyi sebagai berikut:

"Setiap jual beli, penukaran, penghibahan, pemberian dengan wasiat dan perbuatanperbuatan lain yang dimaksudkan untuk langsung atau tidak langsung memindahkan hak milik kepada seorang warga negara yang di samping kewarganegaraan Indonesianya mempunyai kewarganegaraan asing atau kepada suatu badan hukum, kecuali yang ditetapkan oleh pemerintah termaksud dalam Pasal 21 Ayat (2), adalah batal karena hukum dan tanahnya jatuh kepada negara, dengan ketentuan bahwa hak-hak pihak lain yang membebaninya tetap berlangsung serta semua pembayaran yang telah diterima oleh pemilik tidak dapat dituntut kembali"

Hubungan antara pihak WNA dengan WNI sebagai pemberi kuasa (trustee atau nominee) yang diciptakan melalui satu paket perjanjian itu pada hakikatnya bermaksud untuk memberikan segala kewenangan yang mungkin timbul dalam hubungan hukum antara seorang dengan tanahnya kepada WNA selaku penerima kuasa untuk bertindak layaknya seorang pemilik yang sebenarnya dari sebidang tanah yang menurut hukum tidak dapat dipunyainya.

Kedudukan hukum WNA dalam perjanjian semacam itu lemah karena dua alasan. Pertama, walaupun kedua belah pihak cakap bertindak dan mengikatkan diri dengan sukarela, tetapi "causa"nya adalah palsu atau terlarang karena perjanjian itu mengakibatkan dilanggarnya ketentuan Pasal 26 Ayat (2) UUPA. Kedua terkait dengan ketentuan bahwa perjanjian berlaku sebaga Undang-undang bagi mereka yang membuatnya. Mengenai hal ini, Subekti dalam Sumardjono (2007) mengatakan bahwa tidak semua perjanjian yang dibuat mengikat sebagai 
undang-undang. Hanya perjanjian yang dibuat secara sah yang dapat mengikat kedua belah pihak. Dengan demikian, perjanjian antara WNA dengan WNI yang melanggar ketentuan Pasal 26 Ayat (2) merupakan perjanjian yang tidak sah sehingga tidak mempunyai mengikat kedua belah pihak.

Selanjutnya, pada praktek pinjam nama yang dilakukan oleh WNA dapat menghambat terwujudnya tertib administrasi pertanahan. Punia (2001) mengatakan bahwa praktek pinjam nama yang dilakukan oleh WNA dapat menimbulkan ketidakpastian hukum karena adanya perbedaan antara kebenaran formal dalam sertipikat (de jure) dengan kebenaran materiil (de facto) terhadap Hak Milik atas tanah tersebut. Dengan demikian praktek demikian telah menimbulkan cacat pada subyek haknya sehingga dapat menghambat terciptanya catur tertib pertanahan.

\section{B. Faktor Ekonomi/Bisnis}

Aspek ekonomi penting dikaji karena berkaitan erat dengan masalah kesejahteraan masyarakat setempat (Mubyarto, et al, 1991). Selanjutnya, komponen yang penting ditelaah dalam aspek ekonomi menurut Kasmir dan Jakfar (2007) diantaranya:

a. Peningkatan ekonomi rumah tangga melalui:

1. Peningkatan tingkat pendapatan keluarga. Dengan adanya suatu kegiatan usaha akan memberikan suatu peningkatan kepada masyarakat, terutama bagi mereka yang dapat diterima bekerja di lokasi pabrik maupun mereka yang bekerja di luar lokasi pabrik dengan cara berdagang atau lainnya.

2. Perubahan pola nafkah. Di beberapa wilayah kehadiran suatu usaha akan mengubah pola hidup masyarakat. Misalnya, semula masyarakat hidup dari pertanian, dengan kehadiran suatu usaha banyak yang beralih profesi menjadi karyawan pada usaha itu.

3. Adanya pola nafkah ganda. Bagi masyarakat di sekitar lokasi usaha di samping tetap mempertahankan pekerjaan semula seperti bertani, mereka juga bekerja sebagai karyawan, sehingga memperoleh penghasilan ganda.

4. Tersedianya jumlah dan ragam produk barang dan jasa di masyarakat, sehingga masyarakat mempunyai banyak pilihan untuk produk yang diinginkan.

5. Membuka kesempatan kerja bagi masyarakat sekaligus mengurangi pengangguran, karena setiap proyek/ usaha baru yang didirikan pasti akan membutuhkan tenaga kerja tambahan dan hal ini tentu akan membuka peluang bagi tenaga kerja yang belum mendapatkan pekerjaan atau masih menganggur.

6. Tersedianya sarana dan prasarana dengan dibukanya suatu proyek atau usaha dapat pula memberikan fasilitas bagi masyarakat luas maupun pemerintah.

b. Menggali, mengatur, dan Menggunakan ekonomi sumber daya alam, melalui:

1. Pemilikan dan penguasaan sumber daya alam yang teratur, artinya kepemilikan diatur berdasarkan luas lahan, jangan sampai masyarakat kehilangan kesempatan. Demikian pula dengan penguasaan sumber daya alam juga diatur sedemikian rupa. 
2. Penggunaan lahan yang efesien dan efektif, penggunaan lahan yang benar-benar memberikan manfaat kepada berbagai pihak.

3. Peningkatan nilai tambah sumberdaya alam.

4. Peningkatan sumberdaya alam lainnya yang belum terjamah, terutama untuk wilayahwilayah yang masih terisolasi.

c. Meningkatkan perekonomian lokal dan regional melalui:

1. Menambah peluang dan kesempatan kerja dan berusaha bagi masyarakat.

2. Memberikan nilai tambah proses manufaktur.

3. Menambah jenis dan jumlah aktivitas ekonomi nonformal di masyarakat.

4. Pemerataan pendistribusian pendapatan.

5. Menimbulkan efek ganda ekonomi

6. Peningkatan Produk Domestik Regional Bruto.

7. Peningkatan Pendapatan Asli daerah.

8. Menambah pusat-pusat pertumbuhan ekonomi di daerah tertentu.

9. Menyediakan fasilitas umum yang sangat dibutuhkan masyarakat.

10. Menghemat devisa apabila produk dan jasa yang dihasilkan dapat mengurangi pemakain impor barang dan jasa dari luar negeri.

11. Memperoleh pendapatan berupa pajak dari sumber-sumber yang dikelola oleh perusahaan, baik dari pendapatan penjualan maupun dari pajak lainnya.

Aspek lingkungan mempunyai kajian yang sangat luas, terlebih lagi pada Analisis Dampak Lingkungan Hidup (Amdal) yang dilakukan terhadap suatu kegiatan usaha. Namun, pada analisis mengenai model kerjasama pemanfaatan tanah antara WNA dengan penduduk lokal ini perlu diberikan batasan yang sesuai dengan usaha yang dilakukan oleh WNA. Usaha-usaha yang dilakukan oleh WNA di Provinsi Bali sebagaimana telah disebutkan sebelumnya adalah pembangunan hotel atau vila. Dalam hubungannya dengan aspek lingkungan, Brata (2005) mengemukakan bahwa di Bali terdapat sejumlah hotel, vila, dan bangunan lainnya yang menyimpang dari rencana tata ruang wilayah Provinsi Bali, khususnya berkaitan dengan sempadan pantai, sempadan jurang, dan kawasan suci. Berkaitan dengan pernyataan Gubernur tersebut, bahwa di daerah sempadan pantai telah banyak dilakukan pelanggaran-pelanggaran oleh pihak pengelola hotel atau vila. Sempadan pantai sepertinya telah menjadi milik hotel atau vila, sedangkan masyarakat menjadi terpinggirkan (www.iloveblue.com).

Selain gangguan pada sempadan pantai, usaha yang dilakukan oleh WNA juga berdampak negatif bagi keberlangsungan sistem irigasi air. Hal ini sebagaimana dikemukakan oleh Eka (2007) bahwa vila-vila tak berijin ini banyak yang dibangun pada lahan persawahan. Padahal keindahan sawah itu merupakan salah satu daya tarik bagi wisatawan untuk berkunjung ke Bali (www.elshinta.com). Terganggunya sistem irigasi air ini akan mempercepat laju perubahan penggunaan tanah sawah menjadi non pertanian.

\section{Faktor Sosial Budaya}


Menurut Mubyarto et al (1991) Aspek sosial menjadi penting diperhatikan karena adanya penetrasi dari luar budaya masyarakat setempat. Pengaruh dari luar akan memberikan tekanan sosial yang begitu kuat terhadap budaya setempat. Demikian pula halnya investasi yang masuk ke Provinsi Bali telah mempengaruhi tata nilai budaya setempat. Soethama (2008) mengatakan bahwa ketika terdapat pihak yang akan masuk menanamkan modalnya di Provinsi Bali, sesungguhnya masyarakat telah masuk ke dalam perangkap untuk saling bertikai. Masyarakat sangat mudah berseteru dengan sanak saudaranya hanya karena perbedaan pendapat dalam pengalihan tanah warisan. Bagi masyarakat Bali terdapat tata nilai bahwa seseorang tidak dibenarkan untuk menjual tanah warisan. Siapapun yang berani mengalihkan tanah warisan maka akan terkena kutukan dari para leluhur berupa kesusahan dalam kehidupannya. Namun, masuknya arus modal ke Bali yang cenderung menjanjikan kemewahan, sebagian masyarakat cenderung memberanikan diri untuk melanggar tata nilai tersebut dengan cara menjual tanah warisannya. Untuk menghilangkan rasa takut dari kutukan leluhur, maka biasanya sebagian hasil penjualan tanah warisan digunakan untuk melakukan upacara terhadap leluhur atau membangun tempat ibadah di rumah.

Selain fenomena tersebut, majalah Sarad edisi 93 Januari 2008 memberitakan bahwa kemudahan masuknya arus modal ke Bali sering dilakukan dengan cara mempermainkan hukum, bertabrakan dengan kebijakan pusat, memperkosa hak-hak komunitas, hak adat, tata nilai dan tata kultur yang berlaku di Bali. Hal ini sering memicu ketegangan sosio-kultural masyarakat. Dengan demikian kedatangan arus modal ke Bali perlu dicermati secara hati-hati agar tidak membawa petaka bagi masyarakat Bali.

Dalam hubungannya dengan kajian terhadap aspek sosial, Kasmir dan Jakfar (2007) menyatakan bahwa komponen sosial yang perlu ditelaah diantaranya meliputi:

a. Komponen demografi

1. Perubahan struktur penduduk menurut kelompok umur, jenis kelamin, mata pencaharian, pendidikan, dan agama.

2. Perubahan tingkat kepadatan penduduk

3. Pertumbuhan penduduk, tingkat kelahiran, tingkat kematian bayi, dan pola migrasi.

4. Perubahan komposisi tenaga kerja baik tingkat partisipasi angkatan kerja maupun tingkat pengangguran.

b. Komponen budaya

1. Kemungkinan perubahan kebudayaan melalui perubahan adat istiadat, nilai, dan norma budaya setempat.

2. Terjadinya proses sosial baik proses asosiatif/ kerjasama, proses disosiatif konflik sosial, akulturasi, asimilasi, dan integrasi maupun sosial lainnya.

3. Perubahan pranata sosial/ kelembagaan masyarakat di bidang ekonomi seperti hak ulayat, pendidikan, agama, dan keluarga.

4. Perubahan warisan budaya seperti perusakan situs purbakala maupun cagar budaya.

5. Perubahan pelapisan sosial berdasarkan pendidikan, ekonomi, pekerjaan, dan kekuasaan. 
6. Perubahan kekuasaan dan kewenangan melalui kepemimpinan formal dan informal, mekanisme pengambilan keputusan di kalangan individu yang dominan, pergeseran nilai kepemimpinan.

7. Perubahan sikap dan persepsi masyarakat terhadap rencana usaha dan/atau kegiatan.

8. Kemungkinan terjadinya tingkat kriminalitas dan konflik antara warga negara asli dengan pendatang.

c. Perubahan kesehatan masyarakat meliputi terjadinya.

1. Perubahan parameter lingkungan yang diperkirakan terkena dampak rencana pembangunan dan berpengaruh terhadap kesehatan.

2. Perubahan proses dan potensi terjadinya pencemaran

3. Perubahan potensi besarnya dampak timbulnya penyakit, seperti peningkatan angka kesakitan dan angka kematian.

4. Perubahan karakteristik spesifik penduduk yang beresiko terjadi penyakit.

5. Perubahan sumberdaya kesehatan masyarakat.

6. Perubahan kondisi sanitasi lingkungan.

7. Perubahan status gizi masyarakat

8. Perubahan kondisi lingkungan yang dapat mempermudah proses penyebaran penyakit.

\subsection{PENELITIAN TERDAHULU}

Sofian (2006) pada tesisnya dengan judul "Penyelundupan Hukum Oleh Orang Asing Untuk Memperoleh Hak Milik Atas Tanah”.

Penelitian ini bertujuan untuk mengetahui proses penyelundupan hukum yang dilakukan oleh orang asing serta akibat hukum yang ditimbulkan dari perbuatan tersebut. Penelitian ini bersifat normatif. Pendekatan masalah yang digunakan adalah statute approach, yaitu dengan mengkaji hukum atau peraturan perundang-undangan yang berlaku dan mempunyai relevansi dengan materi yang ditulis.

Penelitian dengan topik yang sama juga dilakukan oleh Utama (2006) pada tesisnya dengan judul "Pengaturan Hak-Hak Orang Asing Perseorangan Atas Tanah di Bali". Penelitian ini bertujuan untuk menelaah formulasi masalah praktek penerapan norma pengaturan kepemilikan tanah oleh orang asing untuk lebih jauh menentukan formulasi masalah normatif yang menjadi sebab masalah prakatek kepemilikan tanah tersebut. Tujuan lainnya adalah mengkonstruksi masalah normatif yang menjadi sebab timbulnya masalah praktek yang membuat orang asing cenderung menggunakan nominee (pinjam nama) dalam kepemilikan tanah atau tidak menggunakan hak pakai sebagaimana ditentukan hukum yang berlaku. Penelitian ini merupakan penelitian hukum. Pendekatan masalah yang digunakan adalah statute approach, yaitu dengan mengkaji hukum atau peraturan perundang-undangan yang berlaku dan mempunyai relevansi dengan materi yang ditulis. 
Penelitian dengan topik yang sama juga dilakukan oleh Wijaya (2006) pada tesisnya dengan judul "Penyelundupan Hukum Terhadap Prinsip Nasionalitas Dalam Jual Beli Hak Milik Atas Tanah". Penelitian ini bertujuan untuk menganalisis konstruksi/bentuk penyelundupan hukum terhadap prinsip nasionalitas dalam jual beli hak milik atas tanah dan menganalisis akibat hukum terjadinya penyelundupan hukum terhadap prinsip nasionalitas dalam jual beli hak milik atas tanah. Penelitian ini merupakan penelitian hukum. Pendekatan masalah yang digunakan adalah statute approach, yaitu dilakukan penelitian terhadap aturan-aturan hukum yang dapat digunakan untuk menjawab permasalahan yang telah dirumuskan. Pendekatan peraturan perundang-undangan ini dikombinasikan dengan pendekatan konsep-konsep hukum (conceptual approach).

Penelitian dengan topik pembelian Hak Milik Atas Tanah oleh orang dilakukan oleh Purwanto (2005) pada tesisnya dengan judul "Pembelian Hak Milik Atas Tanah Oleh Orang Asing Dengan Pinjam Nama". Penelitian ini bertujuan untuk memahami dan mengkaji keabsahan menurut hukum dari perjanjian jual beli hak atas tanah dengan pinjam nama yang dilakukan oleh orang asing sehubungan dengan penanaman modalnya di Indonesia serta mengkaji konstruksi hukum yang dapat memberikan perlindungan hukum terhadap investor asing tersebut. Penelitian ini bersifat normatif. Pendekatan masalah yang digunakan adalah statute approach, yaitu dengan mengkaji hukum atau peraturan perundang-undangan yang berlaku dan mempunyai relevansi dengan materi yang ditulis dan juga dilakukan pendekatan kasus (case approach) yang pengkajiannya didasarkan pada putusan pengadilan sehubungan dengan jual beli hak atas tanah dengan pinjam nama.

Penelitian dengan topik yang sama dilakukan oleh Ridjajani (2005) pada tesisnya dengan judul "Kebijakan Pemerintah Dalam Memberikan Hak Pakai Atas Tanah Bagi Orang Asing". Penelitian ini bertujuan untuk menganalisis pembatasan terhadap pemberian Hak Pakai atas tanah untuk hunian bagi orang asing dalam hukum pertanahan serta mengkaji dimungkinkannya setiap orang asing menggunakan hak pakai itu sebagai obyek hak tanggungan. Penelitian ini merupakan penelitian hukum. Pendekatan masalah yang digunakan adalah statute approach, yaitu dengan mengkaji hukum atau peraturan perundang-undangan yang berlaku dan mempunyai relevansi dengan materi yang ditulis.

Penelitian Sumadra dan Sitorus (2003) yang dimuat pada jurnal Widya Bhumi berjudul "Penyelundupan Hukum Dalam Perolehan Hak Atas Tanah Oleh Warga Negara Asing di Provinsi Bali". Penelitian ini bertujuan untuk mendeskripsikan perilaku WNA dalam memperoleh hak atas tanah di Provinsi Bali. Alat analisis yang digunakan adalah deskriptif kualitatif. Hasil penelitian menunjukkan bahwa WNA memperoleh hak atas tanah dengan meminjam nama seorang WNI. Peminjaman nama tersebut ditindaklanjuti dengan pembuatan perjanjian yang semata-mata untuk melindungi kepentingan WNA.

Penelitian Sanusi (2002) di Kota Batam dengan judul "Pemilikan Satuan Rumah Susun/Apartemen Oleh Warga Negara Asing di Kota Batam", menunjukkan bahwa di Kota Batam terdapat sekitar 1.692 orang tenaga kerja WNA. Pada jumlah itu, hanya 43 orang yang membeli apartemen dan sejumlah 29 orang belum mendaftarkan kepemilikannya pada Kantor 
Pertanahan. WNA pada umumnya tidak menyukai prosedur yang berbelit-belit. Oleh karena itu, mekanisme pemberian, perpanjangan, maupun pembaharuan hak juga tidak disukai. Dengan demikian secara materiil di Kota Batam terdapat banyak WNA yang memiliki rumah, namun secara yuridis sulit dibuktikan. Hal ini disebabkan adanya praktek penyelundupan hukum melalui pernikahan di bawah tangan dengan seorang WNI.

\subsection{Kerangka Pikir}




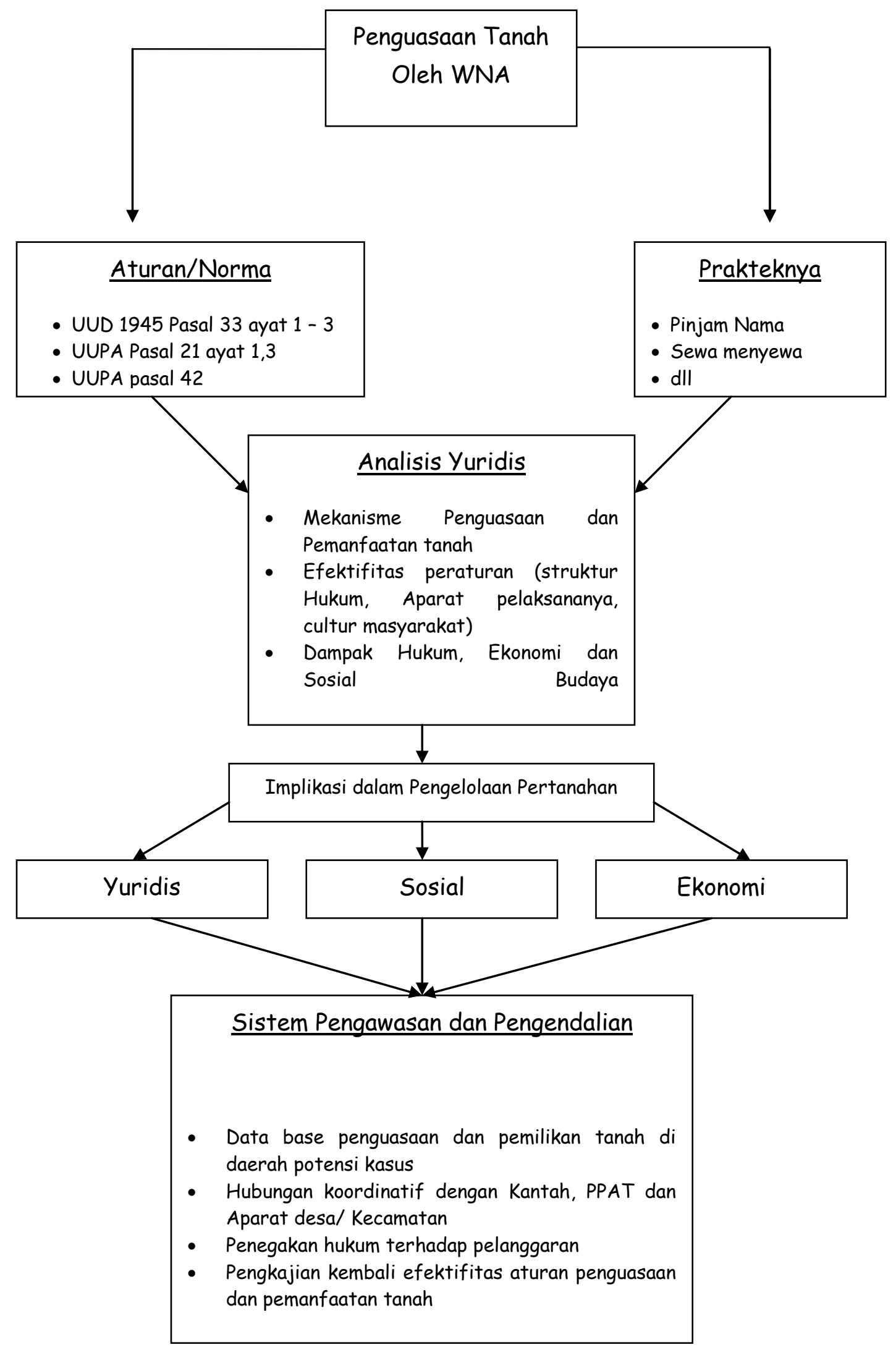




\section{BAB III \\ METODOLOGI}

\subsection{Metode Pendekatan}

Penelitian ini merupakan penelitian yuridis empiris yaitu penelitian yang didasarkan pada penelitian lapangan untuk mendapatkan data primer. Untuk menunjang dan melengkapi penelitian ini maka dilaksanakan penelitian yuridis normative, yaitu penelitian yang didasarkan pada penelitian kepustakaan untuk mendapatkan data sekunder.

Penguasaan tanah oleh WNA secara normative diatur dalam pasal-pasal UUPA, antara lain dalam pasal 42 UUPA yang menyebutkan bahwa yang dapat memiliki Hak Pakai, antara lain adalah orang asing yang berkedudukan di Indonesia. Dengan demikian secara hukum telah jelas bahwa WNA hanya dapat memiliki tanah dengan Hak Pakai. Namun dalam prakteknya, banyak dijumpai penguasaan tanah oleh WNA terhadap tanah Hak Milik maupun Hak Pakai dengan berbagai cara yang diindikasikan merupakan penyelundupan hukum.

Hasil penelitian diharapkan dapat memberikan gambaran yang bersifat deskriptif analisis. Bersifat deskriptif karena dari penelitian ini diharapkan akan diperoleh gambaran secara rinci, sistematis dan menyeluruh tentang segala hal yang berhubungan dengan cara-cara yang dilakukan WNA untuk dapat menguasai tanah dari WNI. Bersifat analisis karena dari hasil penelitian ini akan dilakukan analisis terhadap berbagai aspek hukum yang mendasari dan mengatur tentang penguasaan tanah oleh WNA dari segi teori dan praktek.

\subsection{Lokasi Penelitian}

Untuk mendapatkan data primer, maka lokasi yang dipilih secara purposive sampling, merupakan wilayah yang merupakan potensi wisata dan diindikasikan dapat diperoleh responden yang representative sehingga diperoleh data sesuai dengan masalah yang akan diteliti, yaitu :
a. Provinsi Jawa Barat
b. Provinsi Jawa Timur
c. Provinsi Bali
d. Provinsi NTB
e. Provinsi Kepulauan Riau
f. Provinsi Sulawesi Utara
g. Provinsi Sulawesi Selatan 


\subsection{Responden Penelitian}
a. -Kantor Wilayah : Kepala Kantor Wilayah dan Kepala Bidang I dan II
b. -Kantor Pertanahan : Kepala Kantor Pertanahan dan Kepala Seksi I dan II
c. -PPAT/Notaris di lokasi penelitian
d. -Kepala Desa di lokasi peneitian

\subsection{Bahan Hukum}

a. Bahan hukum primer yaitu bahan hukum yang mengikat berupa Peraturan Perundangundangan, yang berbentuk Undang-undang, Peraturan Pemerintah, Keputusan Presiden, Peraturan Presiden, Instruksi Presiden, Peraturan Menteri, dan Keputusan Menteri sera Kitab Undang-Undang hukum Perdata.

b. Bahan hukum sekunder yaitu buku, artikel majalah atau koran, hasil penelitian atau seminar mengenai penguasaan tanah oleh WNA.

c. Bahan hukum tertier, yaitu kamus hukum, kamus Bahasa Indonesia dan kamus bahasa Inggris.

\subsection{Alat Penelitian}

Pada penelitian ini alat yang digunakan adalah studi dokumen.

\subsection{Pengolahan dan Analisis data}

Data yang telah dikumpulkan baik dari penelitian lapangan maupun dari penelitian kepustakaan akan dianalisis secara deskriptif dengan metode kualitatif.

Data yang diperoleh di lapangan akan dianalisis secara kualitatif terutama yang berkaitan dengan permasalahan yang akan diteliti yaitu :

- Mekanisme Penguasaan dan Pemanfaatan tanah

- Efektifitas peraturan (struktur Hukum, Aparat pelaksananya, cultur masyarakat)

- Dampak Hukum, Ekonomi dan Sosial Budaya.

Dari hasil analisis data tersebut akan diketahui Implikasinya dalam Pengelolaan Pertanahan baik secara yuridis, sosial maupun ekonomi.

Berdasarkan hal tersebut maka perlu diusulkan sistem pengawasan dan pengendalian yang tepat berdasarkan :

- Data base penguasaan dan pemilikan tanah di daerah potensi kasus

- Hubungan koordinatif dengan Kantah, PPAT dan Aparat desa/ Kecamatan 
- Penegakan hukum terhadap pelanggaran

- Pengkajian kembali efektifitas aturan penguasaan dan pemanfaatan tanah.

\section{BAB IV}

\section{HASIL DAN PEMBAHASAN}

\subsection{Profil dan Potensi Daerah}

\subsubsection{Propinsi Jawa Barat}

\section{A. Kabupaten Cianjur}

Cianjur salah satu kabupaten di wilayah Propinsi Jawa Barat berpenduduk 1.931.480 jiwa terdiri dari penduduk laki-laki sebanyak 982.164 jiwa dan perempuan 949.676 jiwa dnegan laju pertumbuhan penduduk 1,48\%. Letak yang strategis dilintasi jalur jalan negara antara Jakarta ¿ Bandung. Luas wilayah 350.148 Ha dan secara administrative Pemerintahan terdiri dari 26 Kecamatan, 338 Desa dan 6 Kelurahan. Kabupaten yang sekarang dipimpin oleh Bupati Ir. H. Wasidi Swastomo, M.Si. ini dikelilingi oleh 5 Kabupaten yang memiliki pantai sepanjang 75 Km. Sebelah utara berbatasan dengan Wilayah Kabupaten Bogor dan Purwakarta, sebelah barat berbatasan dengan wilayah kabupaten Bandung dan Garut sebelah selatan berbatasan dengan Samudera Indonesia.

Kabupaten Cianjur beriklim propis dengan curah hujan per tahun rata-rata 1.000 sampai $4.000 \mathrm{~mm}$ dan jumlah hari hujan rata-rata 150 per-tahun. Dengan iklim tropis tersebut menjadikan kondisi alam Kabupaten Cianjur subur dan mengandung keanekaragaman kekayaan sumber daya alam yang potensial sebagai modal dasar pembangunan dan potensi investasi yang menjanjikan. Lahan-lahan pertanian tanaman pangan dan hortikultura, peternakan, perikanan dan perkebunan merupakan sumber kehidupan bagi masyarakat. Keadaan itu ditunjang dengan banyaknya sungai besar dan kecil yang dapat dimanfaatkan sebagai sumber daya pengairan tanaman pertanian. Dari luas wilayah Kabupaten Cianjur 350.148 hektar, pemanfaatannya meliputi $83.034 \mathrm{Ha}(23,71 \%)$ berupa hutan produktif dan konservasi, 58,101 Ha (16,59\%) berupa tanah pertanian lahan basah, $97.227 \mathrm{Ha}(27,76 \%)$ berupa lahan pertanian kering dan tegalan, $57.735 \mathrm{Ha}(16,49 \%)$ berupa tanah perkebunan, $3.500 \mathrm{Ha}(0,10 \%)$ berupa tanah dan penggembalaan / pekarangan, $1.239 \mathrm{Ha}(0,035 \%)$ berupa tambak / kolam, 25.261 Ha (7,20 \%) berupa pemukiman / pekarangan dan $22.483 \mathrm{Ha}(6.42 \%)$ berupa penggunaan lain-lain.

Lapangan atau pekerjaan penduduk Kab. Cianjur di sektor pertanian yaitu sekitar 62.99 $\%$. Sektor pertanian merupakan penyumbang terbesar terhadap produk Domestik Regional Bruto (PDRB) yaitu sekitar 42,80 \%. Sektor lainnya yang cukup banyak menyerap tenaga kerja adalah 
sektor perdagangan dan jasa yaitu sekitar 14,60\% Beras Pandan Wangi yaitu beras asli Cianjur merupakan satu-satunya beras

Di daerah Cipanas Kecamatan Pacet sekitar $80 \mathrm{~km}$ dari Jakarta atau $20 \mathrm{~km}$ dari kota Cianjur, selain dikenal sebagai kawasan wisata pegunungan, juga merupakan daerah penghasil sayuran. Kawasan sayuran ini kini dikembangkan menjadi kawasan agropolitan hortikultura. Hasil produksi Kabupaten Cianjur, khususnya di sektor pertanian mudah dipasarkan. Hal ini slain karena prod8uksi pertanian merupakan kebutuhan rutin sehari-hari, juga didukung oleh kemudahan-kemudahan pemasaran mengingat lokasi Cianjur berada di lintasan jalur ekonomi regional Jawa Barat. Daerah Pacet sebagai primadona Pariwisata Cianjur memiliki obyek-obyek wisata yang menarik antara lain obyek wisata Pendakian Gunung Gede, Kebun Raya Cibodas, Taman Mandala Kitri untuk kegiatan Pramuka dan Remaja, Kota Bunga serta Taman Bunga Nusantara. Di kecamatan Cikalongkulon terdapat obyek wisata Ziarah Makam Dalem Cikundul yakni Makam Bupati pertama sekitar abad 17. di kecamatan Mande terdapat obyek Wisata Danau Cirata.

\section{B. Kabupaten Bogor}

Kabupaten Bogor merupakan salah satu wilayah yang berbatasan langsung dengan ibukota RI dan secara geografis mempunyai luas sekitar $2.301,95 \mathrm{Km}^{2}$ terletak antara $6.19^{0}$ lintang selatan dan $106^{0} 1^{\prime}-107^{0} 103^{\prime}$ bujur timur.

Wilayah ini berbatasan dengan :

\begin{tabular}{|l|l|l|}
\hline Sebelah Utara & $:$ & Kabupaten Bekasi, Kota Depok, \\
\hline Sebelah Barat & $:$ & Kabupaten Lebak (Prop. Banten) \\
\hline Sebelah Barat Daya & $:$ & Kabupaten Tangerang \\
\hline Sebelah Timur & $:$ & Kabupaten Karawang \\
\hline Sebelah Timur Laut & $:$ & Kabupaten Purwakarta \\
\hline Sebelah Selatan & $:$ & Kabupaten Sukabumi \\
\hline Sebelah Tenggara & $:$ & Kabupaten Cianjur \\
\hline Sebelah Tengah & $:$ & Kotamadya Bogor \\
\hline
\end{tabular}

Kabupaten Bogor memiliki 40 kecamatan, 427 desa/kelurahan, 3.516 RW dan 13.603 RT. Dari jumlah desa tersebut mayoritas mempunyai ketinggian sekitar kurang dari $500 \mathrm{~m}$ terhadap permukaan laut, yakni 234 desa, sedangkan di antara 500 - 700 meter ada 144 desa dan sisanya 49 desa sekitar lebih dari 500 meter dari permukaan laut. 
Wilayah Bogor Bagian Utara corak penduduknya adalah Betawi Ora (atau campuran suku Betawi dan Sunda); Wilayah Bogor Bagian Selatan corak dan bahasa penduduknya adalah campuran antara Bogor dengan Cianjur dan Sukabumi; Sebelah Barat corak dan bahasa penduduknya campuran antara Bogor dan Banten; Bagian Timur corak dan bahasa penduduknya campuran Bogor dengan Karawang, sedikit dengan Cianjur dan Bekasi.

\subsubsection{Propinsi Bali}

\section{A. Kabupaten Badung}

Kabupaten Badung, satu dari delapan kabupaten dan satu kota di Bali, secara fisik mempunyai bentuk unik menyerupai sebilah "keris", yang merupakan senjata khas masyarakat Bali. Keunikan ini kemudian diangkat menjadi lambang daerah yang merupakan simbol semangat dan jiwa ksatria yang sangat erat hubungannya dengan perjalanan historis wilayah ini, yaitu peristiwa "Puputan Badung".

Semangat ini pula yang kemudian melandasi motto Kabupaten Badung yaitu "Cura Dharma Raksaka" yang artinya Kewajiban Pemerintah adalah untuk melindungi kebenaran dan rakyatnya. Terletak pada posisi 08o14'17" - 08o50'57" Lintang Selatan dan 115o05'02" - 115o15' 09" Bujur Timur, membentang di tengah-tengah Pulau Bali. Mempunyai wilayah seluas 418,52 km2 ( 7,43\% luas Pulau Bali ), Bagian utara daerah ini merupakan daerah pegunungan yang berudara sejuk, berbatasan dengan kabupaten Buleleng, sedangkan di bagian selatan merupakan dataran rendah dengan pantai berpasir putih dan berbatasan langsung dengan Samudra Indonesia. Bagian tengah merupakan daerah persawahan dengan pemandangan yang asri dan indah, berbatasan dengan Kabupaten Gianyar dan kota Denpasar disebelah Timur, sedangkan di sebelah Barat berbatasan dengan kabupaten Tabanan.

Kabupaten Badung merupakan daerah berikilim tropis yang memiliki dua musim yaitu musim kemarau (April - Oktober) dan musim hujan (Nopember - Maret), dengan curah hujan rata-rata pertahun antara 893,4 - 2.702,6 mm. Suhu rata-rata 25 - 30oC dengan Kelembaban udara rata-rata mencapai 79\%. Secara administratif Kabupaten Badung terbagi menjadi 6 ( enam ) wilayah Kecamatan yang terbentang dari bagian Utara ke Selatan yaitu Kecamatan Petang, Abiansemal, Mengwi, Kuta, Kuta Utara, \& Kuta Selatan. Disamping itu di wilayah ini juga terdapat 16 Kelurahan, 45 Desa, 1 Desa Persiapan, 361 Banjar Dinas, 148 Lingkungan dan 13 Lingkungan Persiapan.

Selain Lembaga Pemerintahan seperti tersebut di atas, di Kabupaten Badung juga terdapat Lembaga Adat yang terdiri dari 119 Desa Adat, 523 Banjar dan 523 Sekaa Teruna. Di Kabupaten Badung juga terdapat 1 BPLA Kabupaten dan 6 BPLA Kecamatan serta 1 Widyasabha Kabupaten dan 6 Widyasabha Kecamatan. Lembaga - lembaga adat ini memiliki peran yang sangat strategis dalam pembangunan di wilayah Badung pada khususnya dan Bali pada umumnya. Sebagaimana lazimnya sebuah lembaga, anggota masyarakat adat ini terikat dalam suatu aturan adat yang disebut awig - awig. Keberadaan awig-awig ini sangat mengikat 
warganya sehingga umumnya masyarakat sangat patuh kepada adat. Oleh karena itu keberadaan Lembaga Adat ini merupakan sarana yang sangat ampuh dalam menjaring partisipasi masyarakat. Banyak program yang dicanangkan Pemerintah berhasil dilaksanakan dengan baik di daerah ini, berkat keterlibatan dan peran serta lembaga adat yang ada.

\section{B. Kabupaten Gianyar}

Kabupaten Gianyar sebagai salah satu Kabupaten dari 9 (sembilan) Kabupaten/Kota di Bali, oleh banyak kalangan dikenal sebagai "roh"nya Bali. Kabupaten ini kaya akan nilai-nilai adat istiadat, kesenian, keindahan alam, warisan purbakala dan kerajinan seni. Potensi ini juga membawa Gianyar berpredikat sebagai gudang seniman. Sejarahpun telah membuktikan kalau Gianyar banyak melahirkan maestro seni, baik seni patung, seni lukis, seni tabuh, seni tari dan sebagainya. Warisan seni dan budaya yang tak ternilai itupun hingga kini masih berkembang seiring semangat ngayah masyarakat Gianyar dalam pengebdiannya sebagai insan ciptaan Tuhan.

Gianyar juga terkenal dengan objek-objek wisata. Misal kawasan wisata Goa Gajah, Tampak Siring, Gunung Kawi, Kawasan Wisata Gajah di Desa Taro, Bali Zoo Park, pusat-pusat perbelanjaan kerajinan seni, seperti Pasar Seni Sukawati dan Guang serta berbagai obyek wisata lainnya. Demikian juga aktivitas agama, adat dan budaya, sudah menjadi keseharian masyarakat Gianyar, hingga menarik bagi wisatawan sebagai atraksi wisata budaya

Untuk hasil Pertanian, Kabupaten seni ini tidak kalah dengan kabupaten lainnya. Hingga kini Gianyar masih mampu mempertahankan produksi beras dan hasil komoditi pertanian lainnya. Keseniannya ini tentu tak lepas dari kerja keras pemerintah dan masyarakat yang memiliki semangat tinggi untuk membangun.

Kabupaten Gianyar merupakan salah satu dari 9 Kabupaten/Kota yang ada di Propinsi Bali. Secara astronomis terletak diantara $8^{\circ} 18^{\circ} 48^{\circ}$ dan $8^{\circ} 38^{\circ} 58^{\circ}$ Lintang Selatan (LS) dan $115^{\circ} 22^{\circ} 23^{\circ}$ Bujur Timur (BT)

Luas wilayah Kabupaten Gianyar $368 \mathrm{Km}^{2}$ atau 36.800 ha tersebar pada 7 (tujuh) Kecamatan. Secara administrasi Kabupaten Gianyar memiliki 63 Desa dan 6 Kelurahan, banjar Dinas berjumlah 541, dan Desa Adatnya 269 buah serta subak 515 buah. Jumlah penduduk Gianyar tahun 2004 (Supas 2004) mencapai 422.186 jiwa, laki-laki 214.903 jiwa (50,90\%) dan perempuan 207.293 jiwa (49,10\%) dengan tingkat kepadatan $1.147 \mathrm{jiwa} / \mathrm{km}^{2}$.

\subsubsection{Propinsi Nusa Tenggara Barat}

\section{A. Kabupaten Lombok Barat}

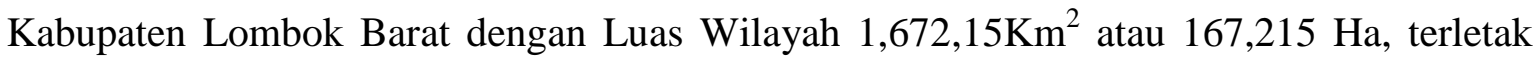
antar 115,46' sampai dengan 11.28 Bujur Timur, dari 8.12 ${ }^{\circ}$ sampai dengan $8.55^{\circ}$ Lintang Selatan batas-batas wilayah yaitu Sebelah Utara Laut Jawa, sebelah Selatan Samudera Indonesia, sebelah 
Barat Selat Lombok dan Kota Madya Mataram, sebelah Timur Kabupaten Lombok Tengah dan Kabupaten Lombok Timur, terbagi dalam 15 Kecamatan

Kabupaten Lombok Barat merupakan salah satu Kabupaten di Propinsi Nusa Tenggara Barat yang menjadi Daerah Tujuan Wisata ( DTW ) yang mempunyai posisi sangat strategis sebagai daerah tujuan wisata dengan iconnya Pantai Senggigi, ketiga Gili di Kecamatan Pemenang dan Pantai Sekotong. Obyek wisata di Kabuapten Lombok Barat terdiri dari obyek wisata alam, obyek wisata sejarah / budaya dan obyek wisata minat khusus, dimana pada tahun 2005 terdapat 37 obyek wisata alam, sejarah / budaya yang terbagi menjadi 3 (tiga) wilayah yaitu wilayah Utara, wilayah Tengah dan wilayah Selatan . Melihat posisi Kabupaten Lombok Barat yang bersebelahan dengan pulau Bali sangat menguntungkan, karena Bali selama ini dianggap sebagai surga wisata bagi tamu asing maupun tamu lakol, sehingga memberikan imbas yang baik bagi Kabupaten Lombok Barat Keindahan alam Lombok Barat tidak kalah menariknya dengan Bali seperti disebutkan diatas antara lain Pantai Senggigi, Tiga Gili ( Gili Air, Gili Trawangan, dan Gili Meno), Gili Gede, Gunung Rinjani

\section{B. Kabupaten Lombok Tengah}

Kabupaten Lombok Tengah adalah salah satu Daerah Tingkat II di Provinsi Nusa Tenggara Barat. Ibu kota daerah ini ialah kota Praya. Kabupaten ini memiliki luas wilayah 1.208,39 km²; dan populasi 745.433 jiwa. Kabupaten Lombok Tengah terletak pada posisi $82^{\circ} 7^{\prime}-8^{\circ} 30^{\prime}$ Lintang Selatan dan $116^{\circ} 10^{\prime}-116^{\circ} 30^{\prime}$ Bujur Timur, membujur mulai dari kaki Gunung Rinjani di sebelah Utara hingga ke pesisir pantai Kuta di sebelah Selatan, dengan beberapa pulau kecil yang ada disekitarnya.

Lombok Tengah adalah salah satu kabupaten di Nusa Tenggara Barat yang telah cukup lama menjadi daerah tujuan wisata. Berjarak hanya 30 kilometer dari Mataram, Lombok Tengah merupakan tempat obyek-obyek wisata penting di pulau Lombok.

Daya tarik utamanya yaitu keindahan pantai-pantai berpasir putih, seperti Pantai Kuta, berbulir sangat khas seperti butiran merica, yang menghadap langsung ke Samudra Hindia dengan ombak yang juga khas yang telah menarik banyak peselancar dan penyelam, juga pecinta keindahan alam dari seluruh dunia untuk datang berkunjung.

\subsubsection{Propinsi Kepulauan Riau}

Kepulauan Riau adalah sebuah provinsi merupakan provinsi baru hasil pemekaran dari provinsi Riau. Provinsi Kepulauan Riau berbatasan dengan :

- di sebelah utara Vietnam dan Kamboja;

- di timur negara Malaysia dan Provinsi Kalimantan Barat; 
- di selatan Provinsi Kepulauan Bangka Belitung dan Jambi;

- di sebelah barat.Negara Singapura, Malaysia, dan Provinsi Riau

Secara keseluruhan Wilayah Kepulauan Riau terdiri dari 4 Kabupaten dan 2 Kota, 47 Kecamatan serta 274 Kelurahan/Desa dengan jumlah 2.408 pulau besar dan kecil dimana $30 \%$ belum bernama dan berpenduduk. Adapun luas wilayahnya sebesar $252.601 \mathrm{Km} 2$, di mana sekitar $95 \%$ - nya merupakan lautan dan hanya sekitar 5\% merupakan wilayah darat.

Provinsi Kepulauan Riau terbentuk berdasarkan Undang-undang Nomor 25 tahun 2002 merupakan Provinsi ke-32 di Indonesia yang mencakup :

- Kota Tanjungpinang,

- Kota Batam,

- Kabupaten Bintan,

- Kabupaten Karimun,

- Kabupaten Natuna, dan

- Kabupaten Lingga

\section{Kabupaten Bintan}

Sebelumnya bernama Kabupaten Kepulauan Riau. Perubahan nama ini dimaksudkan agar tidak timbul kerancuan antara Provinsi Kepulauan Riau dan Kabupaten Kepulauan Riau dalam hal administrasi dan korespondensi sehingga nama Kabupaten Kepulauan Riau (Kepri) diganti menjadi Kabupaten Bintan.Perubahan nama Kabupaten Kepulauan Riau menjadi Kabupaten Bintan sesuai dengan Peraturan Pemerintah Nomor 5 Tahun 2006 tertanggal 23 Februari 2006 Kabupaten ini memiliki sejumlah peluang di bidang pariwisata, industri, perikanan dan pertambangan. Dibidang pariwisata, iklim dan kondisi alam yang eksotis menjadi daya tarik tersendiri bagi para wisatawan mancanegara.

Misalnya Lagoi yang memiliki pemandangan laut dan pantai yang telah menarik minat lebih dari 40.000 wisatawan mancanegara. Dilahan seluas 23.000 ha terdapat 9 resort di kawasan wisata Lagoi, yaitu Nirwana Resort Hotel, Indra Maya Villa, Mayang Sari, Banyu Biru, Nirwana Beach Club, Banyan Tree, Angsana, Club Med dan Bintan Lagoon. Serta 2 lapangan golf bertaraf internasional dengan 36 hole. Lagoi yang diresmikan 18 Juni 1996 oleh Presiden Soeharto bersama dengan PM Singapura Goh Chok Tong, diklaim mampu menjaring 40.000 wisatawan mancanegara setiap bulan. Terbanyak dari Singapura. Dengan menggunakan feri, jarak 45 kilometer yang memisahkan kedua daerah ini dapat ditempuh dalam waktu 45 menit. 
Untuk menarik minat investor, pemerintah setempat telah mengalokasikan lahan seluas 500 ha di Kijang dan 100 ha di Bintan Barat sebagai areal hutan industri dan pengembangan pantai. Pengembangan pariwisata dilakukan dengan bekerja sama dengan Singapura untuk membangun Bintan Utara.

Pada sektor industri, Kabupaten ini mempunyai kawasan industri di Lobam sebagai salah satu hasil dari kerjasama ekonomi antara Singapura, Malaysia, dan Indonesia. Terdapat 4000 ha lahan yang dipakai oleh 18 perusahaan elektronik, 14 perusahaan garmen dan lain-lain.

Industri perikanan juga berperan penting di kabupaten ini dengan didukung oleh luas wilayah perairan seluas 95\%. Para investor di sarankan untuk mengembangkan sektor ini di wilayah dimur yaitu di wilayah Tambelan dengan 54 pulau. Wilayah ini cocok untuk perikanan, dan budidaya terumbu karang seluas 117,480 ha. Pariwisata laut cocok untuk wilayah ini dengan didukung oleh pasir pantai yang bersih dan putih.

\section{Kota Batam}

Kota Batam merupakan sebuah pulau yang terletak sangat strategis karena terletak di jalur pelayaran internasional. Kota ini memiliki jarak yang dekat dengan Singapura dan Malaysia. Kota Batam merupakan salah satu kota dengan pertumbuhan terpesat di Indonesia. Ketika dibangun pada tahun 1970-an awal kota ini hanya dihuni sekitar 6.000 penduduk, dan menurut Dinas Kependudukan dan Pencatatan Sipil Kota Batam hingga Januari 2009 Kota Batam telah berpenduduk 919.449 jiwa dan merupakan kota terbesar dan terpadat ketiga populasinya di Sumatra setelah Medan dan Palembang

Kota yang merupakan bagian dari Provinsi Kepulauan Riau ini memiliki luas wilayah daratan seluas $715 \mathrm{~km}^{2}$ atau sekitar $115 \%$ dari wilayah Singapura, sedangkan luas wilayah keseluruhan mencapai $1.570 .35 \mathrm{~km}^{2}$. Kota Batam beriklim tropis dengan suhu rata-rata 26 sampai 34 derajat celsius. Kota ini memiliki dataran yang berbukit dan berlembah. Tanahnya berupa tanah merah yang kurang subur.

Batas-batas Kota Batam:

- Sebelah utara berbatasan dengan Singapura dan Malaysia

- Sebelah selatan berbatasan dengan Kabupaten Daik-Lingga

- Sebelah timur berbatasan dengan Pulau Bintan dan Tanjung Pinang

- Sebelah barat berbatasan dengan Kabupaten Karimun

Di era Reformasi pada akhir dekade tahun 1990-an, dengan Undang-Undang nomor 53 tahun 1999, maka Kotamadya administratif Batam berubah statusnya menjadi daerah otonomi yaitu Pemerintah Kota Batam untuk menjalankan fungsi pemerintahan dan pembangunan dengan mengikutsertakan Badan Otorita Batam 
Ditetapkannya Pulau Batam sebagai lingkungan kerja daerah industri dengan didukung oleh Otorita Pengembangan Daerah Industri Pulau Batam atau lebih dikenal dengan Badan Otorita Batam (BOB) merupakan penggerak pembangunan Batam.

Selain industry, Investasi di sektor properti di Batam cukup menggiurkan., seperti Superblok Nagoya Hill, Superblok Imperium, Pusat bisnis dan perdagangan Suka Jadi, dan masih banyak lagi. Itu menandakan masih menguntungkan investasi di sektor properti di Batam.

Sesungguhnya yang menjadi menjadi daya tarik Batam hingga pengembang atau investor mau berinvestasi karena Batam itu beda dengan daerah lain di Indonesia. Letaknya sangat dekat dengan Singapura dan Malaysia. Selain itu, Batam merupakan daerah industri yang pekerjanya tidak saja orang Indonesia, tapi juga banyak warga negara asing, terutama dari Singapura. Hal itu menyebabkan kebutuhan perumahan bagi pekerja asing dan lokal cukup tinggi.

\subsubsection{Propinsi Sulawesi Utara}

\section{A. Kota Manado}

Kota Manado terletak di ujung utara Pulau Sulawesi dan merupakan kota terbesar di belahan Sulawesi Utara sekaligus sebagai ibukota Provinsi Sulawesi Utara. Secara geografis terletak diantara $102^{\prime} 88^{\prime \prime}$ - $1039^{\prime} 50^{\prime \prime}$ LU dan $124047^{\prime} 00^{\prime \prime}$ - $124056^{\prime} 00^{\prime \prime}$ BT. Berbatasan dengan Negara Philipina dan menghadap ke Asia Timur serta Pasifik. Luas wilayah Kota Manado adalah 15.726 hektar atau $157.26 \mathrm{~km} 2$ ditambah lahan reklamasi pantai teluk Manado seluas 67 hektar. Secara adminstratif Kota Manado terbagi atas 9 (sembilan) Wilayah Kecamatan dengan 87 (delapan puluh tujuh) Kelurahan.

Sebagai suatu wilayah administratif pemerintahan, kota Manado berbatasan :

- Sebelah Utara dengan Kecamatan Wori (Kabupaten Minahasa Utara) dan Teluk Mana;

- Sebelah Timur, berbatasan dengan Kecamatan Dimembe;

- Sebelah Selatan berbatasan dengan Kecamatan Pineleng;

- Sebelah Barat, berbatasan dengan Teluk Manado/Lauat Sulawesi.

\section{B. Kabupaten Minahasa Utara}

Kabupaten Minahasa Utara terletak di Provinsi Sulawesi Utara dengan ibukota kabupaten berkedudukan di Airmadidi, Kabupaten Minahasa Utara memiliki wilayah keseluruhan 918,49 km2 terdiri atas 8 (delapan) Kecamatan, yaitu :

a. Kecamatan Wori;

b. Kecamatan Likupang Barat;

c. Kecamatan Likupang Timur; 

d. Kecamatan Dimembe;
e. Kecamatan Kauditan;
f. Kecamatan Kema;

Kabupaten Minahasa Utara mempunyai batas wilayah :

- sebelah utara berbatasan dengan Laut Sulawesi;

- sebelah timur berbatasan dengan Kecamatan Bitung Utara dan Kecamatan Bitung Barat Kota Bitung dan Laut Maluku;

- sebelah selatan berbatasan dengan Kecamatan Kombi dan Kecamatan Tondano Utara Kabupaten Minahasa; dan

- sebelah barat berbatasan dengan Kecamatan Tombulu Kabupaten Minahasa, Kecamatan Tikala, Kecamatan Mapanget, dan Kecamatan Bunaken Kota Manado.

\subsubsection{Provinsi Sulawesi Selatan}

\section{A. Kota Makassar}

Kota Makassar mempunyai posisi strategis karena berada di persimpangan jalur lalu lintas dari arah selatan dan utara dalam propinsi di Sulawesi, dari wilayah kawasan Barat ke wilayah kawasan Timur Indonesia dan dari wilayah utara ke wilayah selatan Indonesia. Dengan kata lain, wilayah kota Makassar berada koordinat 119 derajat bujur timur dan 5,8 derajat lintang selatan dengan ketinggian yang bervariasi antara 1-25 meter dari permukaan laut. Kota Makassar merupakan daerah pantai yang datar dengan kemiringan 0 - 5 derajat ke arah barat, diapit dua muara sungai yakni sungai.Tallo yang bermuara di bagian utara kota dan sungai Jeneberang yang bermuara di selatan kota. Luas wilayah kota Makassar seluruhnya berjumlah kurang lebih 175,77 Km2 daratan dan termasuk 11 pulau di selat Makassar ditambah luas wilayah perairan kurang lebih $100 \mathrm{Km}^{2}$. Jumlah kecamatan di kota Makassar sebanyak 14 kecamatan dan memiliki 143 kelurahan. Diantara kecamatan tersebut, ada tujuh kecamatan yang berbatasan dengan pantai yaitu kecamatan Tamalate, Mariso, Wajo, Ujung Tanah, Tallo, Tamalanrea dan Biringkanaya.

Dari gambaran selintas mengenai lokasi dan kondisi geografis Makassar, memberi penjelasan bahwa secara geografis, kota Makassar memang sangat strategis dilihat dari sisi kepentingan ekonomi maupun politik. Dari sisi ekonomi, Makassar menjadi simpul jasa distribusi yang tentunya akan lebih efisien dibandingkan daerah lain. Memang selama ini kebijakan makro pemerintah yang seolah-olah menjadikan Surabaya sebagai home base pengelolaan produk-produk draft kawasan Timur Indonesia, membuat Makassar kurang dikembangkan secara optimal. Padahal dengan mengembangkan Makassar, otomatis akan sangat berpengaruh terhadap peningkatan kesejahteraan masyarakat di kawasan Timur Indonesia dan percepatan pembangunan. Dengan demikian, dilihat dari sisi letak dan kondisi geografis Makassar memiliki keunggulan komparatif dibanding wilayah lain di kawasan Timur Indonesia. Saat ini Kota Makassar dijadikan inti pengembangan wilayah terpadu Mamminasata. 


\section{B. Kabupaten Gowa}

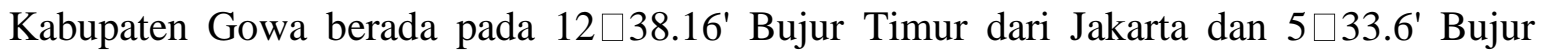
Timur dari Kutub Utara. Sedangkan letak wilayah administrasinya antara 12 $\square 33.19$ ' hingga

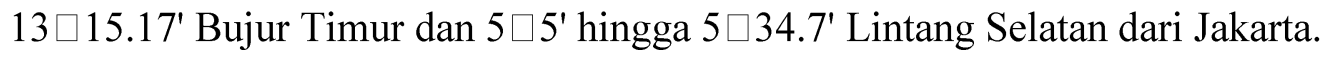

Luas wilayah Kabupaten Gowa adalah 1.883,33 km2 atau sama dengan 3,01\% dari luas wilayah Provinsi Sulawesi Selatan. Wilayah Kabupaten Gowa sebagian besar berupa dataran tinggi berbukit-bukit, yaitu sekitar $72,26 \%$ yang meliputi 9 kecamatan yakni Kecamatan Parangloe, Manuju, Tinggimoncong, Tombolo Pao, Parigi, Bungaya, Bontolempangan, Tompobulu dan Biringbulu. Selebihnya 27,74\% berupa dataran rendah dengan topografi tanah yang datar meliputi 9 Kecamatan yakni Kecamatan Somba Opu, Bontomarannu, Pattallassang, Pallangga, Barombong, Bajeng, Bajeng Barat, Bontonompo dan Bontonompo Selatan. Dan daerah wisata yang terkenal sejak dulu adalah daerah pegunungan di Kelurahan malino Kecamatan Tinggimoncong.

\subsubsection{Provinsi Jawa Timur}

\section{A. Kota Malang}

Kota Malang, adalah sebuah kota di Provinsi Jawa Timur, Indonesia. Kota ini berada di dataran tinggi yang cukup sejuk, terletak $90 \mathrm{~km}$ sebelah selatan Kota Surabaya, dan wilayahnya dikelilingi oleh Kabupaten Malang. Malang merupakan kota terbesar kedua di Jawa Timur, dan dikenal dengan julukan kota pelajar.

Kota Malang sejak masa kolonial dikenal sebagai tempat peristirahatan dan tujuan wisata bangsa Eropa terutama dari Negeri Belanda. Iklim tropis pegunungan yang sejuk dan kaya pemandangan indah serta lingkungan yang alami dikelilingi oleh perkebunan, pegunungan, sungai dan taman menjadikan Kota Malang dikenal sebagai Paris Van East Java dan Switzerland of Indonesia. Kota Malang juga merupakan pusat pertemuan beragam etnik, agama, kepercayaan dan budaya khas Jawa Timur yaitu Jawa Tengahan, Jawa Kulonan, Jawa Wetanan (Blambangan), Pesisi Lor dan Kidul, Madura, Osing (Jawa - Bali) dan Mandalungun (Madura Jawa) sehingga memiliki keunikan serta daya tarik tersendiri.

Kota Malang pada saat ini merupakan tempat persinggahan / transit dan tujuan perbelanjaan serta souvenir / kerajinan rakyat bagi turis domestik dan mancanegara. Kebanyakan lokasi wisata di Jawa Timur berada di wilayah eks Karesidenan Malang (sekarang wilayah Pembantu Gubernur di Malang). Terutama di wilayah Kabupaten Malang dan Kotatif Batu, namun fasilitas pariwisata terlengkap ada di Pusat Kota Malang. Maka Kota Malang telah 
mantap menjadikan wilayahnya sebagai tempat bermukim sementara bagi para turis mancanegara dan domestik.

Sebagai Kota Kenangan bagi turis Eropa terutama Belanda Kota Malang masih tetap sebagai primadona karena banyak peninggalan gedung / bangunan, taman khas warisan kolonial serta tempat bersejarah lainnya tetap dilestarikan oleh Pemda. Namun tidak ditemukan penguasaan atau pemanfaatan tanah oleh WNA secara permanen di kota ini.

\section{B. Kota Surabaya}

Kota Surabaya adalah ibukota Provinsi Jawa Timur, Indonesia. Surabaya merupakan kota terbesar kedua di Indonesia setelah Jakarta. Dengan jumlah penduduk metropolisnya yang mencapai 3 juta jiwa, Surabaya merupakan pusat bisnis, perdagangan, industri, dan pendidikan di kawasan Indonesia timur. Surabaya terkenal dengan sebutan Kota Pahlawan karena sejarahnya yang sangat diperhitungkan dalam perjuangan merebut kemerdekaan bangsa Indonesia dari penjajah. Kata Surabaya konon berasal dari cerita mitos pertempuran antara sura (ikan hiu) dan baya (buaya).

Sebagai kota metropolitan, Surabaya menjadi pusat kegiatan perekonomian di daerah Jawa Timur dan sekitarnya. Sebagian besar penduduknya bergerak dalam bidang jasa, industri, dan perdagangan. Banyak perusahaan besar yang berkantor pusat di Surabaya, seperti PT Sampoerna Tbk, Maspion, Wing's Group, Unilever, dan PT PAL. Kawasan industri di Surabaya diantaranya Surabaya Industrial Estate Rungkut (SIER) dan Margomulyo.

Penguasaan tanah oleh WNA secara nominee diindikasikan banyak terjadi pada apartement, karena apartement dibangun di atas tanah HGB, sehingga orang asing yang ingin membelinya menggunakan prosedur pinjam nama /nominee.

\subsection{Identifikasi Kasus}

\subsubsection{Kantor Pertanahan}

Inventarisasi data yang dilakukan di Kantor Pertanahan di 7 Lokasi penelitian menunjukkan penguasaan tanah oleh warga Negara Asing melalui Hak Pakai sangat rendah, dan hanya terdapat di Provinsi Bali. Di 6 Provinsi lainnya belum pernah ada pemberian Hak Pakai kepada Warga Negara Asing untuk Perorangan. 
Selengkapnya terdapat dalam tabel di bawah ini

Tabel 1 Hak Pakai yang dikuasai oleh Warga Negara Asing (Perorangan) di Provinsi Bali

\begin{tabular}{|l|l|c|l|}
\hline No. & Kantor Pertanahan & $\begin{array}{l}\text { Jumlah Hak Pakai } \\
(2004 \text { s/d 2009) }\end{array}$ & Keterangan \\
\hline 1. & Kab. Badung & 65 & bidang \\
\hline 2 & Kab. Gianyar & 2 & $\begin{array}{l}1 \text { bidang masih dalam } \\
\text { proses }\end{array}$ \\
\hline
\end{tabular}

BPN tidak mengetahui jika terjadi penguasaan tanah oleh Warga Negara Asing melalui perjanjian dengan pemilik tanah karena peralihan haknya tidak didaftarkan ke Kantor Pertanahan. Adanya penguasaan tanah oleh orang asing dengan melalui pinjam nama Warga Negara Indonesia baru diketahui oleh BPN ketika terjadi konflik diantara mereka. Seperti adanya konflik di Kabupaten Gowa yang akhirnya diperkarakan baik di Peradilan Umum di Indonesia maupun di Belanda.

Dalam kasus tersebut, terjadi penguasaan tanah oleh warga negara Belanda yaitu Yohanis Van Riee, yang menggunakan nama atau pinjam nama kepada warga lokal atau warga negara Indonesia bernama J.J Dominggus, tanah yang dimiliki merupakan tanah pertanian, beserta rumah/Villa. Kemudian terjadi konflik karena sang suami menduga sang istri melakukan mark up terhadap harga pembelian tanah pertanian tersebut. Masalah tersebut di bawa oleh suaminya ke Pengadilan Belanda yang menyatakan bahwa haknya di miliki oleh Warga Negara Asing tersebut, sedangkan kasusnya di Peradilan di Indonesia sudah sampai tahap banding.

Kemudian kasus Pulau Bawah dan pulau-pulau sekitarnya yang terletak dikawasan Kepulauan Anambus Desa Kiabu Kec. Sianban Selatan Kabupaten Natuna diindikasikan sudah dijual kepada pihak asing.

Data yang diperoleh menunjukkan :

- adanya fakta jual beli tanah garapan sesama WNI, dari Mukhtar dan keluarga berdasarkan SK Riwayat penguasaan Tanah oleh Kades Kiabu kepada Tasfinardi (karyawan PT Nikoi, perusahaan pariwisata di Pulau Nikoi). Transaksi dilakukan dihadapan Notaris Sri Rahayu dengan menerbitkan 51 Surat Pengoperan dan penyerahan hak atas tanah.

- Tanah garapan yang diperjual belikan berupa kebun kelapa yang sudah tua pada 5 buah pulau yang terdiri dari 51 surat keterangan riwayat kepemilikan/penguasaan tanah dengan perincian sbb: 
(1) P.Bawah dengan luas 63,524 ha (32 surat tanah)

(2) P. Sanggah dengan luas 27,845 ha (14 surat tanah)

(3) P. Elang dengan luas 5, 94 ha (3 surat tanah)

(4) P. Murba dengan luas 1,3 ha ( 1 surat tanah)

(5) P. Lidi dengan luas 1, 13 ha ( 1 surat tanah)

- Keseluruhannya Tasfinardi menguasai tanah seluas \pm 99,327 ha.

Indikasi penguasaan tanah oleh Warga Negara asing juga ditemukan di Kabupaten Bintan dan Kota Batam.

Indikasi penguasaan asing terhadap resort yang disewakan di Lagoi, dimana sewa menyewa mengikuti jangka waktu HGB nya yaitu 30 - 20 - 30, berarti sewa 80 tahun, dan sewa menyewa tersebut dilakukan di Singapore. Sewa menyewa ini mirip dengan jual beli ( disebut sale and purchase), dan mereka menggunakan trustee (semacam perwalian).

Untuk Batam, diindikasikan banyak perumahan dan ruko yang sudah dijual kepada WNA dengan menggunakan nama istri yang WNA. Didaerah ini, lazim disebut sebagai kawin kontrak, dimana suami biasanya berdomisili di Singapore dan pada akhir minggu datang ke Batam.

\subsubsection{Kepala Desa}

Adanya penguasaan tanah oleh orang asing diketahui oleh Kepala Desa atau Lurah walaupun secara administrasi tidak didaftar oleh Kepala Desa/Lurah, karena tanah tersebut masih terdaftar atas nama pemilik lama yang WNI, walaupun faktanya Kepala desa/Lurah mengetahui telah terjadi peralihan hak atas tanah dari WNI kepada WNA.

- Desa Perenenan Kabupaten Badung, Tanah yang dikuasai oleh WNA umumnya telah berubah fungsi, tanah-tanah yang dikuasai oleh WNA sudah berubah fungsi, semula merupakan persawahan yang subur menjadi villa, resort atau bungalow. Demikian juga daerah Pantai di Sekotong dan Kuta, Lombok umumnya sudah berubah fungsi menjadi villa, resort maupun restaurant ataupun cafe.

- $\quad$ Kepala Desa Singakarta (Gianyar barat) I Nyoman Raka mengatakan bahwa warga negara asing yang menetap ada dua orang dari perancis yang melakukan pinjam nama dengan WNI yaitu Anak Agung Anom dan I Wayan Sudira mereka sebagai petani. Penggunaan tanah tersebut semula adalah ladang (tidak produktif) dengan view yang cukup indah yaitu menghadap sungai wos, oleh warga negara asing tersebut dijadikan rumah untuk tempat tinggal dan bukan untuk membuka usaha. Dari segi ekonomi, hal ini sangat memberikan manfaat kepada masyarakat sekitar, terutama untuk tenaga kerja dan pemasukan ke banjar.

- Lurah Bunaken Wolter Panontongan bahwa ada kurang lebih enam orang warga negara asing yang melakukan perjanjian pinjam nama, salah satunya adalah Bapak Yan Balero 
dimana tanahnya telah dijual kepada Rafael kewarganegaraan Jerman. Hal ini karena adanya hubungan kedekatan anatara kedua belah pihak sehingga si warga negara asing tersebut mempercayakan yan Balero untuk di beli tanahnya. Perjanjian tersebut dilakukan atas dasar kepercayaan, dimana si warga asing tersebut juga membayarkan pajak atas tanah dan bangunan tersebut. Hal ini menurut warga ada keuntungan yang didapat apabila si warga negara asing membeli tanah di sekitar Bunaken karena dapat meningkatkan perekonomian mereka dimana banyak warga lokal yang terserap menjadi pekerjanya. Perjanjian kedua kedua belah pihak dibuatkan sebuah Surat Pernyataan oleh Kelurahan mengenai perjanjian tersebut dimana dalam surat pernyataan tersebut mengaskan bahwa tanah tersebut kepemilikannya tetap pada warga setempat karena warga negara asing tidak dapat memiliki tanah. Menurut Lurah Bunaken selama ini tidak pernah terjadi perselisihan dalam arti permasalahan hukum karena dianggapnya para pihak saling tunduk pada perjanjian yang mereka buat.

- di Desa Tugu Utara Kampung Sampai. Di Desa ini terindikasi adanya penguasaan tanah oleh warga negara Timur Tengah yang menggunakan nama atau pinjam nama kepada warga lokal atau warga negara Indonesia, rumah dan bangunan tersebut dimilki oleh Warga negara Timur Tengah yang dibeli dari Acin Hidayat warga Serang Banten. Rumah tersebut disewakan dan dijadikan Vila atau penginapan dimana tarif yang berikan untuk warga negara asing khususnya Timur Tengah RP. 800.000,- per malam sedangkan untuk warga negara Indonesia diberikan tarif Rp. 1.500.000,- per malam. Di Kampung Ciburian desa Tugu Utara juga terindikasi ada 4 warga nya yang melakukan kawin kontrak dengan warga negara asing, di kampung ini telah terjadi beberapa kali perubahan pemilik dimana pemilikan tanah serta bangunan tersebut sudah yang ke empat sedangkan kepemilikan tanahnya masih terdaftar atas nama 1 orang yaitu Abdurahman.

Tabel 2 Penguasaan dan Pemanfaatan Tanah Oleh Warga Negara Asing

\begin{tabular}{|l|l|l|l|l|}
\hline No. & Kota/Kabupaten & Desa/Kelurahan & Pemanfaatan & Keterangan \\
\hline 1. & Kab. Bogor & Tugu & Rumah tinggal & WNA (Arab) \\
\hline 2. & Kab. Badung & Perenenan & Resort, Villa & WNA \\
(Australia)
\end{tabular}




\begin{tabular}{|l|l|l|l|l|}
\hline & & & & Perancis) \\
\hline 6. & Kab. Bintan & Sebong Lagoi & Villa, Hotel,resort & $\begin{array}{l}\text { Berbagai } \\
\text { bangsa }\end{array}$ \\
\hline 7. & Kota Batam & Tanjung Piayu & perumahan & Singapura \\
\hline 8. & Minahasa Utara & Bunaken & Perumahan, villa & Jerman \\
\hline 9. & Gowa & Malino & Pertanian & WNA \\
(Belanda)
\end{tabular}

\subsubsection{Notaris}

Yang paling mengetahui terjadinya peralihan hak dari WNI kepada WNA adalah Notaris. Notaris yang menjadi responden menyatakan bahwa mereka telah memberikan advis kepada para pihak yang akan melakukan jual beli terutama WNA untuk mendaftarkan haknya dengan Hak Pakai namun setelah mengetahui jangka waktu yang diperoleh hanya 25 tahun mereka kurang berminat dan membandingkan dengan negara tetangga kita yaitu Singapore selama 70 tahun dan Malaysia selama 75 tahun. Di Kota Batam, banyak WNA yang membeli ruko, gudang dan sebagainya melalui pengikatan jual beli.

Karena sistem hukum di negara asal WNA tidak mengenal notaris, maka mereka lebih percaya kepada pengacara. Bahkan di Bali ada suatu associate yang khusus menangani permasalahan orang asing yang ingin berinvestasi di Indonesia yaitu Austrindo.

\subsection{Mekanisme Terjadinya Kasus Penguasaan Tanah Oleh Warga Negara Asing}

Adanya keinginan WNA untuk memiliki tanah mendorong mereka untuk berkonsultasi dengan para konsultan hukum dan mendapatkan gambaran mengenai hak atas tanah yang dapat dimiliki oleh orang asing. Selain itu mereka juga mendatangi Notaris/PPAT setelah mendapatkan informasi bahwa Notaris/PPAT yang berwenang untuk membuat akta yang berkaitan dengan tanah. Namun WNA kurang berminat terhadap hak atas yang dimungkinkankan yaitu Hak Pakai dan menganggap jangka waktunya sangat pendek berbeda dengan negara tetangga kita. Karenanya mereka memilih untuk memakai nama WNI untuk memiliki tanah di Indonesia, dengan menggunakan akta Notaris. 


\subsubsection{Pelepasan Hak yang diikuti Permohonan Hak}

Didahului dengan pembuatan akta pelepasan hak atas tanah yang dibuat di hadapan Notaris, WNA tersebut kemudian mengajukan permohonan Hak Pakai kepada Kepala Kantor Wilayah Propinsi melalui Kepala Kantor Pertanahan Kota/Kabupaten.

Permohonan Hak Pakai tersebut berisi :

a) keterangan mengenai data pemohon,

b) keterangan mengenai tanah yang dimohon (letak, luas, batas-batasnya, status tanahnya, jenis tanah, penguasaannya dan penggunaannya),

c) keterangan mengenai tanah yang dipunyai pemohon,

d) keterangan mengenai surat-surat yang dilampirkan, bukti kewarganegaraan, bukti perolehan hak, dilampirkan pula identitas pemohon berupa :

- passport, visa, kartu ijin tinggal tetap dan IKTA (ijin kerja tenaga asing) yang dikeluarkan oleh Departemen Tenaga Kerja RI,

- Salinan Akta Pelepasan Hak Atas Tanah,

- asli sertipikat Hak Milik yang dilepaskan haknya,

- SPPT/PBB atas tanah yang dimohon dan bukti pelunasan Pph

- Surat Pernyataan di bawah tanganbermaterai yang memuat pernyataan bahwa dengan memperoleh Hak pakai atas bidang tanah tersebut is tidak akan mempunyai sesuatu hak atas tanah lebih dari satu bidang, bahwa tanah tersebut akan dipergunakan hanya untuk rumah tempat tinggal, bahwa di atas tanah tersebut telah berdiri bangunan rumah tinggal milik dari pihak yang melepaskan hak dan tanah tersebut tidak berada dalam sengketa.

\subsubsection{Penurunan Hak (Istilah Umum)}

Melalui proses ini terlebih dahulu harus dimohonkan penurunan hak oleh WNI yang memiliki tanah kepada Kepala Kantor Pertanahan, setelah terbir sertipikat Hak Pakai atas nama WNI baru kemudian dibuatkan akta jual beli dari WNI kepada WNA.

\subsubsection{Hak Pakai di atas tanah Hak Milik}

Hak Pakai diberikan untuk jangka waktu selama 20 tahun oleh pemegang Hak Milik. Setelah haknya berakhir, maka kembali menjadi Hak Milik si pemegang hak semula. 


\subsubsection{Pinjam Nama}

Dengan nominee agreement ini, WNA dapat membeli dan menguasai bidang tanah dengan hak milik yaitu dengan cara membeli tanah dengan menggunakan nama dan didaftarkan atas nama WNI. Setelah sertipikat atas tanah tersebut terbit atas nama WNI (teman WNA tersebut) maka dibuatkan (pola pertama):

- akta wasiat,

- akta Pengakuan Utang,

- akta Surat Kuasa Untuk Membebankan Hipotik, akta Surat Kuasa untuk menjual dan

- akta Pernyataan Bersama. Setelah minuta akta-akta tersebut ditanda tangani oleh para pihak, para saksi dan Notaris, maka Notaris mengeluarkan salinannya. Salinan dari semua akta tersebut berikut asli Sertipikat Hak Milik atas tanah-tanah tersebut disimpan oleh WNA tersebut.

Ada pula pola lain, pola kedua, tanah yang dibeli WNA dari WNI itu, disertai dengan:

- akta pengakuan utang dan pemberian jaminan tanah, yang bertujuan untuk mencegah WNI yang secara formal adalah pemilik, untuk mengalihkan/menjaminkan tanah tersebut kepada pihak lain yang akan dapat merugikan si WNA tersebut Karena dengan dibebaninya tanah tersebut dengan Hak Tanggungan, maka dalam buku tanah yang terdapat di kantor Pertanahan, telah terdaftar Hak Tanggungan atas tanah Hak Milik tersebut. Oleh karenanya WNI yang secara formal adalah pemilik tanah, tidak akan dapat mengalihkan tanah tersebut kepada pihak lain dan tidak juga dapat mempergunakan tanah tersebut sebagai jaminan sebelum ada bukti pelunasan/peroyaan dari WNA. Dengan pengakuan utang dan pemberian jaminan saja tidak memberikan kewenangan kepada WNA untuk menguasai dan memanfaatkan tanah tersebut yang merupakan tujuan dari WNA. Sehingga, oleh Notaris dibuatkanlah

- akta Sewa Menyewa yang merupakan alas hak bagi WNA untuk menguasai dan memanfaatkan tanah tersebut.

Pola ketiga di Batam, Perjanjian yang ditempuh :

- Perjanjian Induk terdiri dari Perjanjian Pemilikan Tanah (Land Agreement) dan Surat Kuasa.

- Perjanjian Sewa Menyewa. Dalam Perjanjian ini diatur tentang jangka waktu sewa berikut perpanjangan serta hak dan kewajiban pihak yang menyewakan (WNI) dan penyewa (WNA).

- Hibah Wasiat, pihak WNI menghibahkan tanah Hak Milik dan Bangunannya kepada pihak WNA. 


\subsubsection{Percampuran harta karena perkawinan}

Wanita (WNI) menikah dengan Pria (WNA) atau sebaliknya, dengan tanpa membuat perjanjian kawin. Maka terjadi percampuran harta secara bulat berdasarkan pasal 119 KUHPerdata

\subsubsection{Sewa Menyewa}

Dalam perjanjian ini diatur tentang jangka waktu sewa berikut perpanjangan serta hak dan kewajiban pihak yang menyewakan (WNI) dengan penyewa (WNA). Sewa yang diberikan selama 20 tahun, kemudian diperpanjang 10 tahun, cara ini juga lebih diminati oleh WNA.

\subsubsection{Bagi Hasil}

Yang memiliki tanah adalah WNI, kemudian di atas tanah itu dibangun ruko oleh orang asing dengan perjanjian setelah selesai dibangun misalnya menjadi 9 ruko maka dilakukan bagi hasil dengan proporsi $3: 1$ (yang bangun : yang punya tanah). Cara ini banyak ditemukan di Kota Batam.

\subsubsection{Alasan dilakukannya pembelian tanah oleh WNA melalui pinjam nama WNI terutama karena :}

- WNA ingin membeli beberapa bidang tanah yang dapat digunakan sebagai tempat tinggal dan tempat usaha, sedangkan dalam PP No. 41 tahun 1996 hanya dapat diberikan 1 bidang tanah dengan Hak Pakai untuk rumah tinggal.

- Jangka Waktu untuk Hak Pakai kurang menarik dibandingkan dengan Hak Guna Bangunan dan Hak Milik.

- Tanah yang akan dibeli berstatus Hak Milik atau Hak Guna Bangunan sehingga WNA enggan untuk mengurus penurunan haknya.

- Meskipun Hak Pakai dapat dijadikan Hak Tanggungan namun Bank sebagai kreditor lebih memilih yang dijadikan jaminan adalah HGB.

\subsection{Sistem Pengawasan dan Pengendalian Yang Efektif}

\subsubsection{Pengendalian terhadap penguasaan tanah Hak Milik oleh Warga Negara Asing melalui pinjam nama, sewa dan lainnya.}

Mayoritas Responden menyatakan bahwa pengendalian sangat penting untuk dilakukan melalui : 
- Inventarisasi sehingga diperoleh data base terhadap penguasaan pemilikan dan pemanfaatan tanah, dengan adanya data base ini dapat diketahui jika terjadi perubahan penggunaan dan pemanfaatan tanah Hak Milik oleh WNA.

- Pembinaan PPAT

Selain pengendalian, sosialisasi PP Nomor 41 tahun 1996 dan PMNA Nomor 7 tahun 1996 juga penting dilakukan, karena mungkin saja masalah ini terjadi karena kurangnya pemahaman WNA terhadap hukum pertanahan di Indonesia atau informasi dan saran yang kurang tepat yang diterima oleh para WNA.

Adapun solusi terhadap permasalahan ini adalah :

- Perlu adanya peraturan yang mengatur tentang larangan dan sanksi terhadap peralihan HM atau HGB kepada WNA dan institusi yang berwenang menangani.

- Revisi terhadap PP Nomor 41 tahun tahun 1996 dengan memasukkan bab mengenai sanksi yang dapat diberikan terhadap WNA yang melakukan peralihan hak secara nominee.

\section{BAB V \\ PEMBAHASAN}

\subsection{Identifikasi penguasaan tanah oleh WNA}

\subsubsection{Pengertian Warga Negara Asing}

Siapakah yang termasuk WNA yang dapat diberikan Hak Pakai. Dalam pasal 42 UUPA disebutkan bahwa yang dapat memiliki Hak Pakai antara lain adalah orang asing yang berkedudukan di Indonesia. Istilah "berkedudukan" tidak dijumpai dalam tafsiran otentik Penjelasan Umum UUPA, namun dari pemahaman segi hukum tata negara, pengertian "berkedudukan adalah sama dengan bertempat tinggal.

Untuk dapat berkedudukan di Indonesia, dalam Undang-Undang Nomor 9 tahun 1992 tentang Keimigrasian, pasal 1 butir 6 yang dimaksud dengan "orang asing" ialah orang bukan warga negara Republik Indonesia. Ada 2 golongan orang asing di Indonesia yaitu:

1. Orang asing pendatang ialah mereka yang mendapat izin masuk (admission) dengan memperoleh hak untuk tinggal di Indonesia dalam waktu tertentu yang dikenal dengan orang asing pemegang visa.

2. Orang asing penetap ialah mereka yang diperbolehkan tinggal tetap di Indonesia dan diwajibkan memperoleh ijin menetap dengan memperoleh Surat Keterangan Kependudukan, yang dikenal dengan tenaga asing atau tenaga asing domestik.

Orang asing ini dari segi kehadirannya di Indonesia dapat dibagi menjadi 2 golongan, yaitu : 
1. Orang asing yang bertempat tinggal di Indonesia secara menetap (penduduk Indonesia);

2. Orang asing yang tidak tinggal di Indonesia secara menetap melainkan hanya sewaktuwaktu berada di Indonesia.

Dalam UU Nomor 23 tahun 2006 tentang Administrasi Kependudukan, yang dimaksud Orang Asing adalah orang bukan Warga Negara Indonesia dan dibagi menjadi orang asing yang memiliki izin tinggal tetap dan orang asing yang memiliki ijin tinggal terbatas.

Permasalahan yang timbul dengan adanya ijin bagi dua golongan orang asing untuk tinggal di Indonesia dalam kaitannya dengan kemungkinan pemberian Hak Pakai bagi mereka adalah WNA yang manakah yang dapat diberikan Hak Pakai.

Jika dikaitkan dengan pasal 1 PP Nomor 41 tahun 1996, bahwa orang asing yang berkedudukan di Indonesia dapat memiliki sebuah rumah untuk tempat tinggal atau hunian dengan hak atas tanah tertentu, yang kehadirannya di Indonesia memberikan manfaat bagi pembangunan nasional.

Dalam penjelasan pasal 1 tersebut, disebutkan bahwa mengenai keharusan untuk berkedudukan di Indonesia, tampaknya kian perlu dijabarkan secara bijaksana.Secara konkrit, tidak perlu harus diartikan sama dengan tempat kediaman atau domisili. Di bidang ekonomi, misalnya ; orang dapat memiliki kepentingan yang harus dipelihara tanpa harus menunggunya secara fisik, apalagi untuk waktu yang panjang dan secara terus menerus. Kemajuan di bidang teknologi transportasi dan komunikasi, memungkinkan orang memelihara kepentingan yang dimilikinya di Negara lain tanpa harus menungguinya sendiri. Kadangkala, mereka cukup hadir berkala. Dalam keadaan seperti itu, yang mereka perlukan adalah fasilitas tempat tinggal atau hunian bila secara berkala tetapi teratur harus datang untuk mengurus atau memelihara kepentingannya.

Kemudian dalam Peraturan Pelaksanaan PP Nomor 41 tahun 1996 yaitu PMNA Nomor 7 tahun 1996 Tentang Persyaratan Pemilikan Rumah Tempat Tinggal Atau Hunian Oleh Orang Asing, ditambahkan bahwa orang asing yang memberi manfaat bagi pembangunan nasional adalah orang asing yang memiliki dan memelihara kepentingan ekonomi di Indonesia dengan melaksanakan Investasi untuk memiliki rumah tempat tinggal atau hunian di Indonesia.

Dengan pasal ini jelas membeli rumah di Indonesia berarti sudah melakukan investasi dan memenuhi persyaratan untuk diberikan Hak Pakai.

\subsubsection{Menurut Ketentuan Hukum Singapura}

Walaupun sistem hukum yang berlaku di Singapura dan di Indonesia berbeda, namun sebagai perbandingan perlu dilihat bagaimana negara lain menangani masalah pemilikan tanah dan/atau bangunan oleh WNA. Di singapura masalah pemilikan tanah/bangunan untuk hunian diatur dalam residential Property Act tahun 1976. Pada prinsipnya, kecuali ditentukan lain, WNA tidak diperkenankan menerima hak, memberi, atau memperoleh tanah dan/atau bangunan untuk hunian (pasal 3) 
Adapun yang dimaksud dengan WNA atau foreign person adalah : (1) mereka yang bukan warga negara Singapura; (2) mereka yang memperoleh status sebagai permanent resident (berkedudukan tetap); (3) badan hukum asing; dan (4) perkumpulan yang anggotanya sebagian atau seluruhnya bukan warga negara Singapura.

Namun WNA tidak diperkenankan untuk membeli seluruh apartemen dalam sebuah bangunan yang terdiri dari 6 lantai serta seluruh satuan/unit dalam suatu knodominium tanpa ijin dari Menteri (Minister for Law). Pelanggaran terhadap kewajiban yang berkenaan dengan ketentuan tersebut mengakibatkan, bahwa yang bersangkutan dikenakan denda sebesar 10.000 dollar Singapura, ditambah denda sebesar 500 dollar Singapura Singapura untuk setiap hari selama pelanggaran itu terjadi. Menteri dapat memberikan ijin (dengan atau tanpa syarat) kepada WNA yang bermaksud membeli atau memperoleh hak atas tanah dan/atau bangunan untuk digunakan sebagai hunianbagi dirinya sendiri beserta keluarganya, dan tidak dimaksudkan untuk disewakan atau digunakan untuk tujuan lain (pasal 25 ayat 5). Termasuk dalam kategori ini adalah :

- Mereka yang dapat digolongkan sebagai permanent resident/berkedudukan tetap;

- .mereka yang memiliki kualifikasi tertentu berdasarkan pendapat Menetri, yakni secara ekonomis menguntungkan Singapura atau telah nyata-nyata atau diharapkan dapat memberikan sumbangan secara ekonomis kepada Singapura atau;

- Mereka yang memiliki kualifikasi profesional atau pengalaman yang bernilai atau memberikan manfaat bagi Singapura.

\subsubsection{Menurut Ketentuan Hukum Filipina}

Orang Asing dapat memiliki tanah di Filipina melalui mekanisme antara lain :

- Lease Property - Menyewa lahan umum dan pribadi selama 25 tahun dengan perpanjangan otomatis selama 25 tahun, (hanya cukup waktu untuk pengembalian investasi). Ini juga merupakan alternatif murah, tapi itu membuatnya sulit untuk membuat semacam investasi pada properti. Namun, ideal bagi mereka yang berpikir untuk pensiun di sini. Tidak seperti banyak negara seperti Thailand atau Indonesia, sewa properti untuk orang asing yang sangat mudah dan langkah mudah untuk mengambil di Filipina. Ini adalah yang paling mudah, paling tidak memakan waktu, dan cara paling aman bagi orang asing untuk membeli lahan kecil di Filipina. Hal ini dapat dilakukan secara langsung dengan pemilik.

- Melalui Perkawinan dengan penduduk lokal

- Buy A Condominium Unit - WNA dapat memiliki 100\% dari unit tetapi tidak lebih dari $40 \%$ dari seluruh proyek kondominium.

- Membentuk Corporation - WNA dapat membentuk sebuah perusahaan dengan filipina mitra dengan pembagian $40 \%$ asing - $60 \%$ filipina modal. Ini adalah yang 
paling berbaju besi-bentuk kepemilikan properti untuk investor asing, dan pasti yang lebih disukai bentuk kepemilikan properti bagi mereka yang bermaksud mendirikan sebuah resor, atau fasilitas pariwisata. Pada kenyataannya, sebagian besar resort yang ada dan bisnis yang dimiliki oleh orang asing menggunakan bentuk kepemilikan ini.

- Mewarisi tanah jika suami/istri meninggal: bagian 7 pasal XII dari konstitusi Filipina menyatakan bahwa orang asing dapat menjadi ahli waris bersama-sama dengan anakanak, sehinga dapat menjadi pemilik yang sah secara hukum.

\subsection{Mekanisme Penguasaan tanah oleh WNA}

Kurangnya pemahaman WNA untuk memperoleh hak atas tanah di Indonesia menjadi salah satu penyebab terjadinya kasus-kasus pinjam nama. Untuk itu sosialisasi PP Nomor 41 tahun 1996, PMNA Nomor 7 tahun 1996 jo PMNA No. 8 tahun 1996 sangat penting untuk ditingkatkan. Selain itu perlu ada petugas di Kantor Pertanahan terutama daerah potensi wisata seperti Bali, Lombok, Kepulauan Riau dan Sulawesi Utara yang dapat berkomunikasi dalam bahasa Inggris dan memberikan pemahaman kepada WNA yang datang ke Kantor Pertanahan. Sehingga penguasaan tanah melalui pinjam nama tidak terjadi lagi.

Skema 1 : Mekanisme Penguasaan Tanah oleh WNA secara faktual

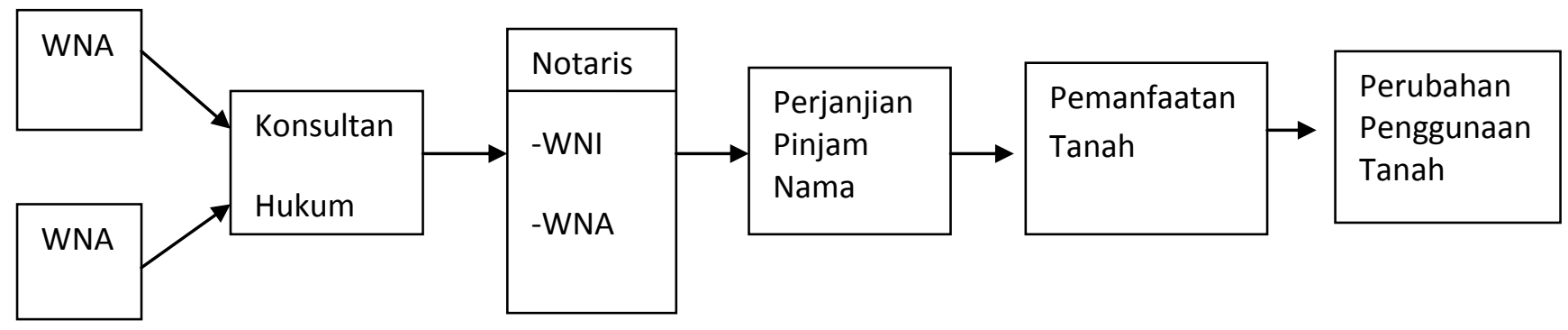

Skema 2 : Mekanisme yang seharusnya

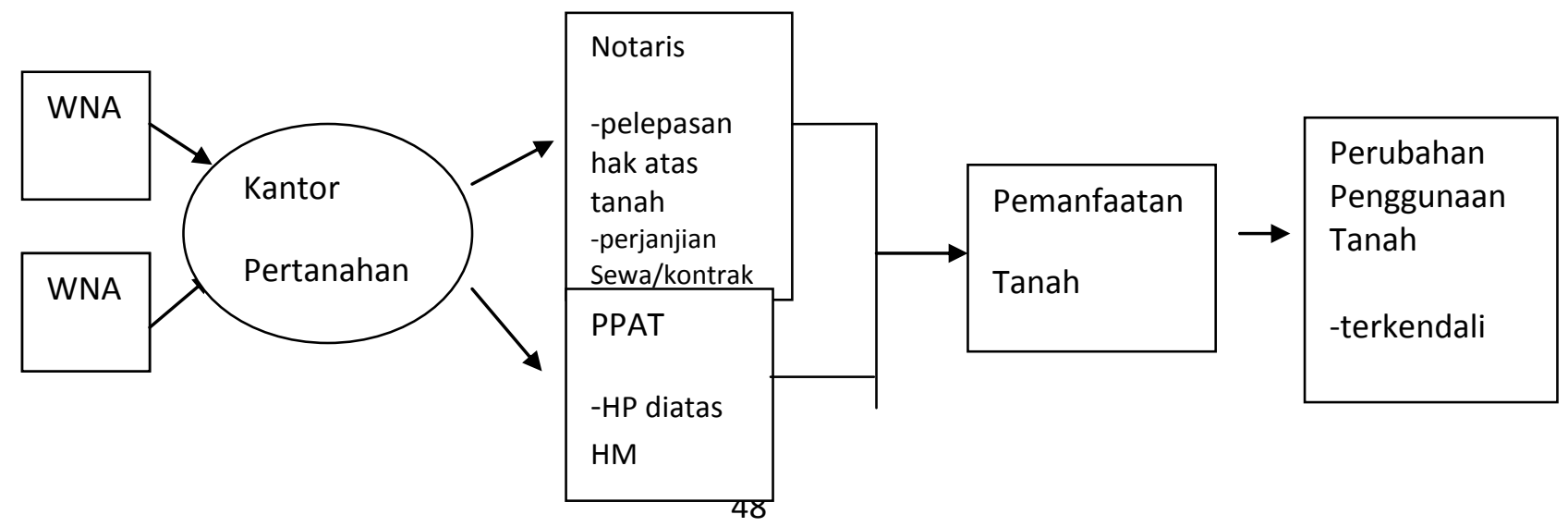




\subsubsection{Perjanjian Pinjam Nama (Nominee Agreement )}

Nominee agreement merupakan salah satu contoh dari perjanjian innominaat. Perjanjian innominaat merupakan perjanjian yang dibuat berdasarkan asas kebebasan berkontrak sebagaimana yang dimaksud dalam pasal 1338 dan pasal 1320 KUHPer. Namun perjanjian innominaat tidak diatur secara khusus di dalam KUHPer. KUHPer menyebutnya didalam pasal 1319 sebagai perjanjian yang tidak terkenal dengan suatu nama tertentu. Walaupun tidak diatur secara khusus dalam KUHPer, perjanjian innominaat tetap harus tunduk pada peraturanperaturan yang termuat di dalam Buku III KUHPer, terutama asas-asas hukum perjanjian yang terkandung di dalamnya.

Hukum perjanjian yang diatur dalam KUHPer menganut sistem terbuka. Ketentuan sistem terbuka ini tersirat dalam pasal 1338 ayat (1) KUHPer, yang menyatakan bahwa "semua perjanjian yang dibuat secara sah berlaku sebagai undang-undang bagi mereka yang membuatnya". Pengertian dari sistem terbuka tersebut adalah bahwa di dalam membuat perjanjian, para pihak diperbolehkan untuk memilih tunduk pada pasal-pasal dalam hukum perjanjian yang tercantum dalam KUHPer atau membuat ketentuan-ketentuan sendiri yang menyimpang dari pasal-pasal hukum perjanjian sesuai dengan kepentingan dan kesepakatan para pihak dalam perjanjian. Atau dengan kata lain sistem terbuka memberikan peluang kepada subyek hukum yang ingin membuat perjanjianm untuk menyingkirkan pasal-pasal dalam hukum perjanjian yang termuat dalam KUHPer bila mereka menghendakinya dan membuat sendiri ketentuan-ketentuan yang menyimpang dari pasal-pasal dalam dalam hukum perjanjian yang termuat dalam KUHPer. Kebebasan untuk membuat sendiri aturan-aturan dalam perjanjian sesuai dengan kepentingan dan kesepakatan para pihak tersebut dikenal dengan istilah "asas kebebasan berkontrak".

Pasal 1338 KUHPer juga menyiratkan suatu asas dalam Hukum Perjanjian yang disebut sebagai asas pacta sunt servanda, yaitu azas yang menyatakan bahwa sebagai akibat dari perjanjian yang dibuat secara sah maka perjanjian tersebut mengikat dan berlaku sebagai undang-undang bagi para pihak dalam perjanjian.

\subsubsection{Perjanjian Pinjam Nama (Nominee Agreement) dalam Hukum Tanah Nasional}

Dasar perundang-undangan dari hukum tanah nasional adalah Undang-Undang Nomor 5 tahun 1960 tentang Peraturan Dasar Pokok-Pokok Agraria. UUPA memuat konsepsi, asas-asas dan ketentuan-ketentuan pokok dari hukum tanah nasional.

Dari segi syarat sahnya perjanjian, perjanjian pinjam nama tersebut adalah sah, karena memenuhi asas kebebasan berkontrak yang diatur dalam hukum perdata. Namun yang menjadi 
pertanyaan apakah asas kebebasan berkontrak dapat diartikan sebagai bebas mutlak? apabila kita mempelajari KUH Perdata, ternyata asas kebebasan berkontrak itu bukannya bebas mutlak.

Ada beberapa pembatasan yang diberikan oleh pasal-pasal KUH Perdata terhadap asas ini. diatur dalam pasal 1320 jo 1335 jo 1337 bahwa :

- Suatu persetujuan tanpa sebab, atau yang telah dibuat karena sesuatu sebab yang palsu atau terlarang, tidak mempunyai kekuatan.

- Suatu sebab adalah terlarang, apabila dilarang oleh Undang-Undang, atau apabila berlawanan dengan kesusilaan baik atau ketertiban umum.

Harus diperhatikan latar belakang dibuatnya perjanjian tersebut karena WNA ingin menguasai tanah dengan hak milik, yang secara hukum jika dilakukan melalui peraturan pertanahan yang berlaku tidak diperbolehkan.

Ketentuan Pasal 21 UUPA menyatakan bahwa (1) Hanya warganegara Indonesia dapat mempunyai hak milik; (2) Oleh Pemerintah ditetapkan badan-badan hukum yang dapat mempunyai hak milik dan syarat-syaratnya; (3) Orang asing yang sesudah berlakunya Undangundang ini memperoleh hak milik karena pewarisan tanpa wasiat atau percampuran harta karena perkawinan, demikian pula warganegara Indonesia yang mempunyai hak milik dan setelah berlakunya undangundang ini kehilangan kewarganegaraannya wajib melepaskan hak itu di dalam jangka waktu satu tahun sejak diperolehnya hak tersebut atau hilangnya kewarganegaraan itu. Jika sesudah jangka waktu tersebut lampau hak milik itu tidak dilepaskan, maka hak tersebut hapus karena hukum dan tanahnya jatuh pada Negara, dengan ketentuan bahwa hak-hak pihak lain yang membebaninya tetap berlangsung; (4) Selama seseorang di samping kewarganegaraan Indonesianya mempunyai kewarganegaraan asing maka ia tidak dapat mempunyai tanah dengan hak milik dan baginya berlaku ketentuan dalam ayat (3) pasal ini.

Selanjutnya dalam pasal 26 UUPA menyebutkan bahwa (1) Jual-beli, penukaran, penghibahan, pemberian dengan wasiat, pemberian menurut adat dan perbuatan-perbuatan lain yang dimaksudkan untuk memindahkan hak milik serta pengawasannya diatur dengan Peraturan Pemerintah; (2) Setiap jual beli, penukaran, penghibahan, pemberian dengan wasiat dan perbuatan-perbuatan lain yang dimaksudkan untuk langsung atau tidak langsung memindahkan hak milik kepada orang asing, kepada seorang warganegara yang disamping kewarganegaraan Indonesianya mempunyai kewarganegaraan asing atau kepada suatu badan hukum, kecuali yang ditetapkan oleh Pemerintah termaksud dalam pasal 21 ayat (2), adalah batal karena hukum dan tanahnya jatuh kepada Negara.

Pembatasan terhadap asas kebebasan berkontrak juga dapat disimpulkan melalui pasal 1338 ayat (3) yang menyatakan bahwa suatu perjanjian hanya dilaksanakan dengan itikad baik. Oleh karena itu para pihak tidak dapat menentukan sekehendak hatinya klausul-klausul yang 
terdapat dalam perjanjiian tetapi harus didasarkan dan dilaksanakan dengan itikad baik. Perjanjian yang didasarkan pada itikad buruk misalnya penipuan mempunyai akibat hukum perjanjian tersebut dapat dibatalkan. Sehubungan dengan pembatasan terhadap asas kebebasan berkontrak Prof. Asikin Kusuma Atmadja, menyatakan bahwa Hakim berwenang untuk memasuki/meneliti isi suatu kontrak apabila diperlukan karena isi dan pelaksanaan suatu kontrak bertentangan dengan nilai-nilai dalam masyarakat. Dengan demikian asas kebebasan berkontrak yang terdapat dalam pasal 1338 tidak lagi bersifat absolut, yang berarti dalam keadaan tertentu hakim berwenang melalui tafsiran hukum untuk meneliti dan menilai serta menyatakan bahwa kedudukan para pihak dalam suatu perjanjian berada dalam keadaan yang tidak seimbang sedemikian rupa, sehingga salah satu pihak dianggap tidak bebas untuk menyatakan kehendaknya.

Perjanjian melalui Pinjam Nama (nominee Agreement) sangat berpotensi untuk terjadinya konflik diantara para pihak yaitu WNI dan WNA, hal ini bahkan sudah ditemukan kasusnya di Cianjur, Badung dan Gowa.

\subsection{Sistem Pengawasan dan Pengendalian}

Ada beberapa alasan yang digunakan WNA menggunakan mekanisme pinjam nama, terlepas dari itu semua yang menjadi pertanyaan apakah mekanisme ini akan dibiarkan berjalan terus tanpa ada solusi untuk mengatasinya. Kemudian instansi manakah yang berwenang untuk melakukan pengawasan dan pengendalian terhadap pelanggaran ketentuan 21 ayat 3 dan pasal 26

Ayat 2 tersebut, yang menyatakan batal karena hukum dan tanahnya jatuh kepada Negara.

Kemudian kaitannya dengan pasal 26 ayat 2 UUPA adalah UU No. 12 tahun 2006 tentang Kewarganegaraan, bagaimana status tanah yang diwarisi oleh anak-anak hasil perkawinan campuran dimana mereka mempunyai kewarganegaraan ganda dan dapat menentukan status kewarganegaraannya setelah usia 18 tahun.

Untuk mengatur instansi yang berwenang mengendalikan dan melakukan kontrol terhadap berbagai fenomena tersebut di atas perlu di atur dalam peraturan perundang-undangan, dan instansi yang melakukan pengendalian tidak dapat hanya BPN saja, tapi perlu ada koordinasi dengan Departemen Hukum dan HAM (Imigrasi) dan Kepolisian yang secara hukum paling mengetahui keberadaan WNA yang masuk ke Indonesia. 


\section{BAB VI}

\section{KESIMPULAN DAN REKOMENDASI}

\subsection{Kesimpulan}

a) Era globalisasi dan kebijakan investasi saat ini memungkinkan terus meningkatnya orangorang asing untuk berinvestasi dan menetap di Indonesia, hal tersebut perlu diantisipasi dengan peraturan perundang-undangan yang memberi kemudahan asing memiliki tanah di Indonesia dengan beberapa pembatasan dan tetap memperhatikan azas keadilan bagi rakyat.

b) BPN tidak mengetahui jika terjadi penguasaan tanah oleh Warga Negara Asing melalui perjanjian dengan pemilik tanah karena peralihan haknya tidak didaftarkan ke Kantor Pertanahan. Adanya penguasaan tanah oleh orang asing dengan melalui pinjam nama Warga Negara Indonesia baru diketahui oleh BPN ketika terjadi konflik diantara mereka. Seperti adanya konflik di Kabupaten Gowa yang akhirnya diperkarakan baik di Peradilan Umum di Indonesia maupun di Belanda.

c) Mekanisme penguasaan tanah oleh WNA selama ini terjadi umumnya menggunakan caracara yang dianjurkan oleh konsultan hukum yang dianggap lebih memudahkan bagi para WNA, antara lain melalui :

- Percampuran harta karena perkawinan

- Pewarisan

- Pinjam Nama WNI yang disertai dengan akta pengakuan utang, akta wasiat, Kuasa membebankan Hipotik, kuasa untuk menjual dan pernyataan bersama atau menggunakan akta pengakuan utang disertai pemberian jaminan tanah dan perjanjian sewa menyewa.

d) Terjadinya kasus pinjam nama oleh WNA antara lain karena :

- WNA ingin membeli beberapa bidang tanah yang dapat digunakan sebagai tempat tinggal dan tempat usaha, sedangkan dalam PP No. 41 tahun 1996 hanya dapat diberikan 1 bidang tanah dengan Hak Pakai untuk rumah tinggal.

- Jangka Waktu untuk Hak Pakai kurang menarik dibandingkan dengan Hak Guna Bangunan dan Hak Milik. Jangka waktu Hak Pakai yang diberikan sangat singkat sehingga jika investasi dilakukan maka waktu 25 tahun belum dapat mengembalikan modal usaha

- Tanah yang akan dibeli berstatus Hak Milik atau Hak Guna Bangunan sehingga WNA enggan untuk mengurus penurunan haknya. 
- Meskipun Hak Pakai dapat dijadikan Hak Tanggungan namun Bank sebagai kreditor lebih memilih yang dijadikan jaminan adalah HGB.

e) Pengendalian dan pengawasan terhadap kasus penguasaan tanah oleh WNA melalui caracara di atas bukan merupakan kewenangan BPN karena tidak ada peraturan yang mengatur mengenai hal tersebut dan dalam tupoksi BPN juga tidak diatur mengenai hal tersebut sehingga dianggap bukan merupakan kewenangan BPN.

\subsection{Rekomendasi}

a) Perlu dilakukan inventarisasi penguasaan dan pemanfaatan tanah yang dikuasai oleh WNA, dan kejelasan tupoksi unit kerja yang menangani inventarisasi tersebut.

b) Sosialisasi PP No. 41 tahun 1996 sangat penting, bukan hanya bagi WNA, tapi juga bagi pihak Pemerintah Daerah, developer dan perbankan untuk menyamakan persepsi, termasuk juga mendorong pembangunan apartement di atas tanah Hak Pakai, karena selama ini apartement umumnya dibangun di atas tanah Hak Guna Bangunan dengan alasan jangka waktu yang lebih lama dari Hak Pakai dan pihak Bank lebih menyukai Hak Tanggungan di atas tanah HGB. Sosialisasi ini juga sekaligus menjelaskan dampak negatif penguasaan tanah melalui pinjam nama dan memberikan gambaran kasus yang terjadi dibeberapa tempat.

c) Perlunya revisi PP No. 40 tahun 1996 mengenai :

Jangka waktu Hak Pakai disamakan dengan Hak Guna Bangunan yaitu 30 tahun, sehingga tidak terjadi nominee terhadap apartemen yang umumnya dibangun di atas tanah HGB, karena walaupun Hak Pakai dapat dijadikan jaminan utang sama dengan HGB namun developer umumnya membangun apartement di atas tanah HGB dengan alasan pihak Bank lebih memprioritaskan HGB untuk dijadikan jaminan utang.

c) Revisi terhadap PP No. 41 tahun 1996, terutama mengenai :

- Hak Pakai tidak hanya untuk rumah untuk hunian tetapi juga untuk tempat usaha.

- Adanya sanksi yang dapat diberikan terhadap WNA yang melakukan peralihan hak atas tanah secara nominee. Dalam UU No. 25 tahun 2007 pasal 33 ayat 1 dan 2 peralihan saham secara nominee dilarang,

- Diatur instansi yang berwenang melakukan pengawasan

d) Revisi PMNA No. 7 tahun 1996, mengenai persyaratan orang asing yang dapat membeli tanah, apakah harus mempunyai visa tetap atau dapat dengan visa kunjungan, disesuaikan dengan UU tentang Imigrasi. 